\title{
PRIRAŠČANJE NAVADNE SMREKE (Picea abies (L.) Karst.) IN EVROPSKEGA MACESNA (Larix decidua Mill.) NA NEKDANJIH NOVINAH V KOPRIVNI V KARAVANKAH
}

\section{GROWTH OF NORWAY SPRUCE (Picea abies (L.) Karst.) AND EUROPEAN LARCH (Larix decidua Mill.) ON FORMER SLASH AND BURN FARMING AREAS IN KOPRIVNA IN THE KARAVANKE MOUNTAINS}

\author{
Janez GOLOB ${ }^{1}$, Tom LEVANIČ2 ${ }^{2}$, David HLADNIK ${ }^{3}$ \\ (1) Univerza v Ljubljani, Biotehniška fakulteta, Oddelek za gozdarstvo in obnovljive gozdne vire, golobjanez@hotmail.com \\ (2) Gozdarski inštitut Slovenije, Univerza na Primorskem, Fakulteta za matematiko, naravoslovje in informacijske tehnologije, \\ tom.levanic@gozdis.si \\ (3) Univerza v Ljubljani, Biotehniška fakulteta, Oddelek za gozdarstvo in obnovljive gozdne vire, david.hladnik@bf.uni-lj.si
}

\begin{abstract}
IZVLEČEK
Na podlagi meritev v obdobju 1962-2017 smo na raziskovalnih ploskvah na nekdanjih novinah v katastrski občini Koprivna izračunali debelinske, višinske in volumenske prirastke za najpomembnejši drevesni vrsti - smreko in macesen. Na raziskovalnih ploskvah, ki so bile prepuščene naravnemu razvoju, so srednjetemeljnični premeri manjši, število dreves pa večje od tistih v primerljivih gospodarskih gozdovih. V zadnjih tridesetih letih se je zaradi visokih sestojnih gostot zmanjšalo debelinsko priraščanje dreves smreke in macesna. $Z$ dendrokronološko analizo smo ocenili vpliv klimatskih dejavnikov na priraščanje smreke in macesna. Na podlagi dendrokronološke analize smo ugotovili, da se leta z negativnim odzivom dreves v debelinskem prirastku od leta 1984 pojavljajo pogosteje.
\end{abstract}

Ključne besede: raziskovalne ploskve, smreka, macesen, debelinski prirastek, volumenski prirastek, indeks gostote SDI, dendrokronološka analiza

\begin{abstract}
IZVLEČEK
Based on previous measurements from 1962 to 2017 on forest research plots located on former slash-and-burn farming areas in the cadastral municipality of Koprivna, the diameter and height increment as well as volume increments of the two main tree species - spruce and larch - were calculated. These set-aside natural research plots have a smaller mean basal area diameter, but the number of trees is higher than in comparable managed forests. Due to the high-density of tree stands over the past thirty years, radial increment of spruce and larch has declined. To determine the influence of environmental factors on radial growth of spruce and larch, a dendrochronological analysis was conducted. According to the dendrochronological analysis of radial increment of trees, the number of years with a negative response has been higher since 1984.
\end{abstract}

Key words: research plots, Norway spruce, European larch, diameter increment, volume increment, stand density index, dendrochronological analysis

\section{UVOD}

1 INTRODUCTION

Začetki opazovanja in analiziranja drevesnih vrst na raziskovalnih ploskvah segajo že v 19. stoletje. Med prve navedbe v evropskem gozdarstvu uvrščajo raziskovalne ploskve na Danskem iz leta 1852 (Marell in Leitgeb, 2005), v Nemčiji so prve ploskve za spremljanje rasti in donosov gozda postavili leta 1870 (Pretzsch in sod., 2019), v Franciji 1882, v Švici leta 1888 (Koehl in sod., 1995), podobno tudi v Avstriji. Na Slovenskem so raziskovalne ploskve začeli postavljati leta $1948 \mathrm{v}$ gospodarsko pomembnih gozdovih z optimalno zgrad- bo le leto zatem, ko je bila končana prva splošna inventarizacija slovenskih gozdov in je bil ustanovljen Gozdarski inštitut Slovenije (Cividini in Wraber, 1950). Raziskovalci našega inštituta so na raziskovalnih ploskvah v smrekovih gozdovih na Pokljuki in Jelovici sprva nameravali ugotoviti optimalne razmere za proizvodnjo kakovostnega smrekovega lesa, kasneje pa so raziskovalne ploskve postavili tudi v gozdovih Pohorja, Gorjancev, Kočevske in na Notranjskem.

Trajne raziskovalne ploskve dajejo pomembne in nezamenljive informacije za znanost in prakso. Prav zaradi tega trajnih raziskovalnih ploskev ne bi smeli 
opuščati, vendar so v zadnjih desetletjih stroški njihovega vzdrževanja pretehtali njihove koristi. Vzpostavljanje novih trajnih raziskovalnih ploskev je dolgotrajen proces, ki pogosto ne prinese rezultatov v nekaj desetletjih. Obstoječe trajne raziskovalne ploskve bi morali vzdrževati in na njih opravljati ponovne meritve, saj je njihovo opuščanje preuranjena odločitev, s katero lahko izgubimo pomembne in nezamenljive informacije o razvoju gozdih sestojev. Kljub temu, da trajne raziskovalne ploskve ne dajejo več odgovorov na prvotna raziskovalna vprašanja, lahko z njihovim spremljanjem preučujemo aktualna znanstvena vprašanja (spreminjanje drevesne sestave, odpornost na sušo, odpornost gozdov na naravne motnje) (Pretzsch in sod., 2019).

V Sloveniji je malo trajnih raziskovalnih ploskev, ki so se ohranile do danes in na katerih bi opravljali meritve več desetletij (Čokl, 1961; Čokl, 1971; Hladnik in Skvarča, 2009; Hladnik in Levanič, 2021). Med tiste raziskovalne ploskve, ki jih spremljamo najdlje, zagotovo spadajo tudi raziskovalne ploskve, ki jih je zasnoval prof. Mlinšek na opuščenih fratah in novinah v Koprivni na Koroškem. Na teh raziskovalnih ploskvah spremljamo sukcesijski razvoj gozda že od leta 1962. Sledile so še meritve v letih 1965, 1968, 1972, 1990 in 2017. Na podlagi pričevanja starejših prebivalcev Koprivne oz. lastnikov gozdov, v katerih so trajne raziskovalne ploskve, pa poznamo tudi začetek zaraščanja teh ploskev z gozdom.

Katastrska občina Koprivna je bila v preteklosti videti bistveno drugače. Na površinah današnjih gozdov so kmetje na fratah in novinah pridelovali hrano za preživetje, gozdov pa je bilo zelo malo. Golob (2018) je predstavil spremembe površine gozdov skozi zgodovino. V letu 1890 je bila ocenjena gozdnatost $33 \%$, v letu 1962 , ko so na teh raziskovalnih ploskvah začeli z meritvami, je bila $67 \%$, do leta 2017 pa se je povečala na $90 \%$. Po opuščanju fratarjenja in novinarjenja so bili ti gozdovi prepuščeni naravnemu razvoju in so do leta 1962 obsegali kar polovico takratne površine gozdov. Zato je na opuščenih fratah in novinah prof. dr. Dušan Mlinšek vzpostavil raziskovalne ploskve $\mathrm{z}$ namenom spremljanja sukcesijskega razvoja teh gozdov, ki bodo za lastnike pomemben vir prihodkov na kmetijah. Razvoj gozdov na nekdanjih novinah so ocenjevali tudi v Estoniji in na Švedskem, prikazan je bil tudi pregled novinarjenja v drugih evropskih državah (Golob, 2018; Golob in sod., 2019). Podatki iz trajnih raziskovalnih ploskev v Koprivni so izredno pomembni, saj zajemajo daljše časovno obdobje in nam kažejo sukcesijski razvoj gozdov, višinske, debelinske in tudi volumenske prirastke $v$ tej alpski dolini.
$\mathrm{Na}$ pomen spremljanja stalnih raziskovalnih ploskev so opozarjali tudi raziskovalci v Sloveniji (Diaci, 1992; Diaci, 2006; Hladnik in Skvarča, 2009; Kotar, 2011). Pri spremljanju stalnih raziskovalnih ploskev lahko gre za preučevanje razvoja gozdov, ki so bili prepuščeni naravnemu razvoju ali preučevanju različnih gozdnogojitvenih ukrepov. Ob spremljanju sukcesijskega razvoja naravi prepuščenih sestojev je pomembno analizirati tudi morebitne spremembe klimatskih dejavnikov in njihov vpliv na razvoj gozdnih sestojev. Take analize je mogoče zanesljivo izpeljati $\mathrm{z}$ dendrokronološkim raziskovanjem.

Stopar (2018) je primerjal priraščanje smrek na naravnih in spremenjenih rastiščih smreke. Z dendrokronološko analizo smrek je ugotovil, da ni značilnih razlik v priraščanju smreke na antropogenih in naravnih rastiščih. Prav tako je ugotovil, da na priraščanje smreke v Sloveniji bolj kot količina padavin in temperatura vplivajo predvsem kakovost rastišča, relief in nadmorska višina. Na nižjih legah je ugotovil tudi vplive klimatskih sprememb na debelinsko priraščanje. Ocenil je, da klimatske spremembe v zadnjih 30-ih letih vplivajo na priraščanje smreke. Levanič in sod. (2008) so z dendrokronološko analizo na dveh lokacijah v Sloveniji preučevali občutljivost smreke za klimatske dejavnike. Širine branik dreves s Sorškega polja so bile bolj variabilne kot pri drevesih s Pokljuke. Pri vplivu padavin in temperatur niso ugotovili korelacij s širino branik. Drevesa v alpskem prostoru (Pokljuka) so imela šibek pozitiven odziv $\mathrm{v}$ širini branik pod vplivom poletnih temperatur. Nasproten odziv pa so imela drevesa iz nižin (Sorško polje), ki so imela šibek negativen odziv v širini branik. Na podlagi slabega odziva dreves iz obeh lokacij so sklepali, da na širino branik bolj kot temperature in padavine vplivajo razlike $\mathrm{v}$ matični podlagi, reliefu in nadmorski višini.

Namen prispevka je na podlagi preteklih meritev (Golob, 1992; Golob, 2018) na 16 trajnih raziskovalnih ploskvah v Koprivni ugotavljati spremembe temeljničnega premera, dominantnega premera, dominantne višine, števila dreves na hektar, indeksa sestojne gostote, temeljnice in lesne zaloge. Spremembe bomo pojasnjevali tudi $\mathrm{z}$ morebitnim vplivom klimatskih dejavnikov na rast in razvoj dreves na območju Koprivne. Z izvrtki iz dreves smo ugotavljali trend debelinskega priraščanja macesna in smreke v odvisnosti od klime.

Izračunali smo debelinske in višinske prirastke dreves v obdobju meritev. Ker so bila zadnja merjenja dreves opravljena v letih 1972, 1990 in 2017, sta bili obdobji 18 in 27 let predolgi, da bi lahko zanesljivo ocenjevali trende priraščanja dreves in jih primerjali z izsledki, ki jih pridobimo $\mathrm{v}$ desetletnih ali celo petletnih obdobjih. 
V obeh obdobjih smo ocenjevali sestojne gostote, ki jih bilo mogoče primerjati s sestojnimi gostotami podobne starosti na primerljivih rastiščih in na podlagi gozdarskih tablic donosov, ki so bile na Slovenskem prirejene in preizkušene. Oblikovali smo naslednje hipoteze:

- Sestojne gostote in priraščanje smreke na rastiščih nekdanjih novin, kjer so bili sestoji prepuščeni naravnemu razvoju, se razlikujejo od tistih na primerljivih naravnih rastiščih v prvobitnih gospodarskih gozdovih.

- Debelinski prirastek smreke je v odvisnosti od klimatskih razmer $\mathrm{v}$ zadnjih desetletjih statistično drugačen kot v obdobju pred tem; $\mathrm{z}$ dendrokronološko analizo bomo ocenili, ali je mogoče zaznati vpliv podnebnih sprememb v zadnjem času.

Primerjava sukcesijskega razvoja sestojev na Koprivni z gospodarskimi gozdovi na podlagi tablic donosov je le grobo izhodišče, kajti med predhodnimi raziskovanji (Golob in sod., 2019) je bil do leta 1972 v sestojni temeljnici ocenjen prevladujoč delež pionirskih drevesnih vrst breze, sive in zelene jelše, trepetlike ter ive. Smreka je dosegla prevladujoč delež po letu 1990. Zadnji obdobji opazovanja smo uporabili za oceno, ali so sestoji na območju nekdanjih novin dosegli nižje sestojne gostote in slabše priraščajo od primerljivih sestojev v gospodarskih gozdovih.

\section{PREDSTAVITEV OBJEKTA IN METODE DELA}

\section{STUDY AREA AND METHODS}

Katastrska občina Koprivna je alpska dolina v povirju reke Meže med Raduho (2062 m.n.v.), Olševo (1930 m.n.v.) in Peco (2126 m.n.v.) (slika 1 in slika 2). V katastrski občini Koprivna prevladuje zasebna gozdna posest. Prevladujejo samotne kmetije oziroma celki. Velikost večjih celkov je med 100 in 150 ha. Koprivna je geološko in geografsko del Karavank, zanjo je značilna pestra geološka sestava. Relief je razgiban. Strma pobočja se spuščajo proti reki Meži. Podnebje v Koprivni je alpskega značaja, saj dolino obdajajo Peca, Olševa in Raduha. Zime so dolge in mrzle. Sneg se v dolini obdrži do pozne pomladi. Poletja so kratka in topla. Vegetacijska doba je kratka in traja ob maja do septembra (Golob, 2018).

Vsa drevesa na ploskvah imajo določene pravokotne koordinate, označena so $\mathrm{z}$ aluminijasto ploščico $\mathrm{s}$ številko, ki pomaga pri identifikaciji posameznih dreves. Ob vseh meritvah je bilo vsako drevo ocenjeno po klasifikaciji IUFRO (Mlinšek, 1968; Kotar, 2011) glede na socialni sloj, vitalnost, razvojno težnjo, gozdnogojitveno vlogo, dolžino krošnje in kakovost debla. Z merskim trakom je bil izmerjen prsni premer dreves na $\mathrm{mm}$ natančno. Prav tako je bila izmerjena tudi višina vseh dreves na ploskvah, v letu 1990 z višinomerom SUUNTO, ob zadnji meritvi leta 2017 pa z višinomerom Haglöf Vertex IV. Izvrtke smo odvzeli v septembru leta

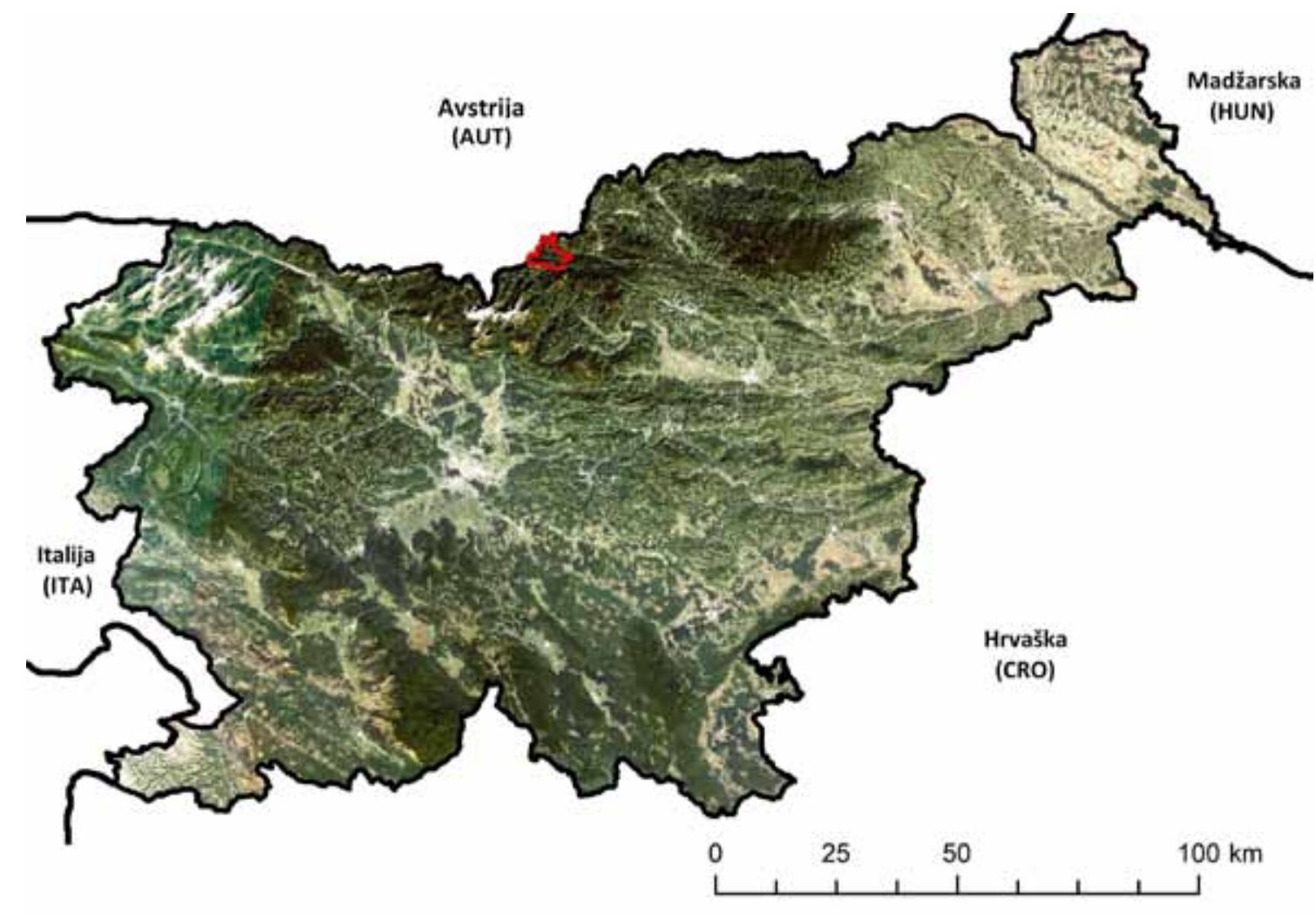

Slika 1: Lega katastrske občine Koprivna na karti Slovenije (GURS, 2016)

Fig. 1: Location of the Koprivna cadastral municipality on the map of Slovenia (GURS, 2016) 


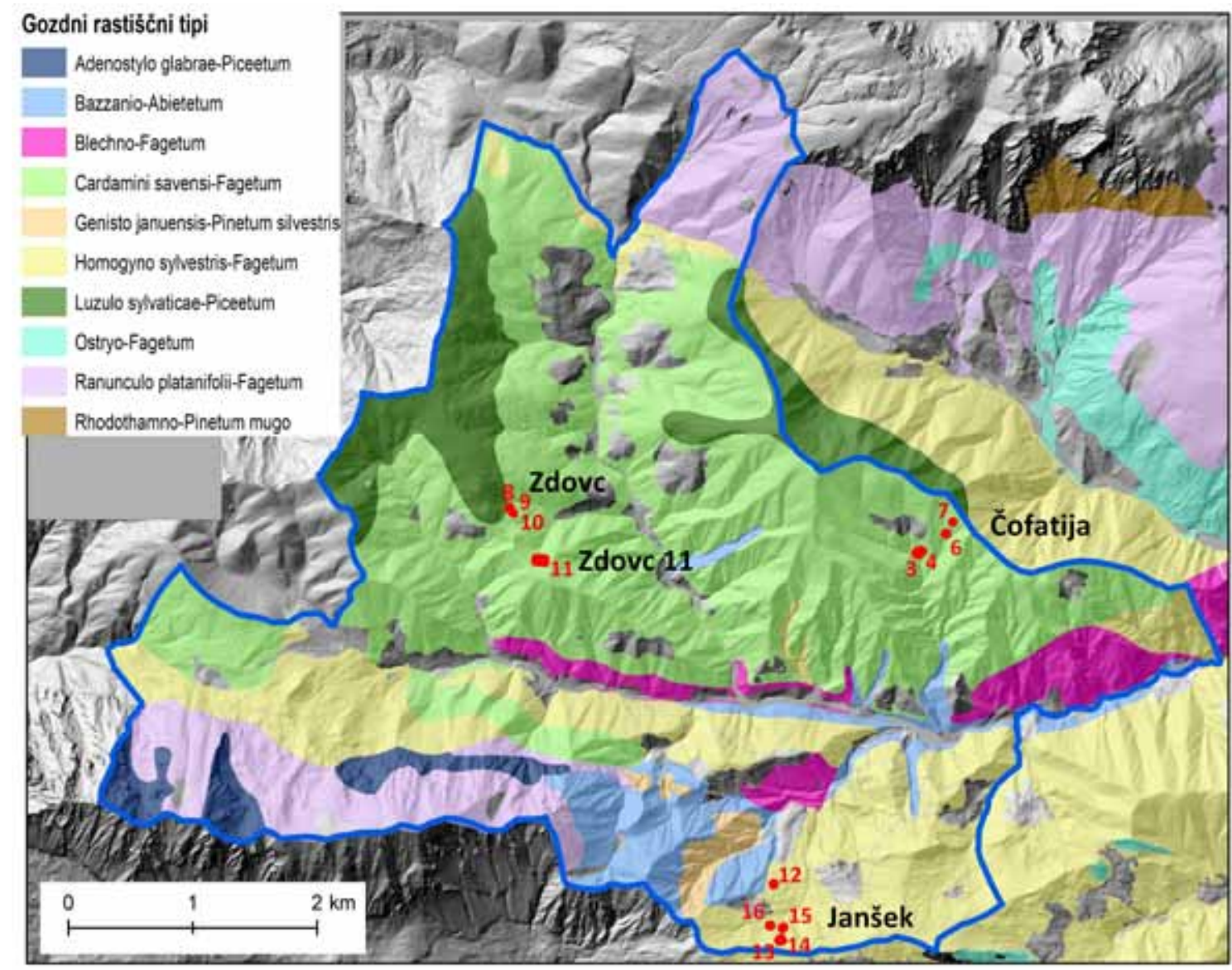

Slika 2: Senčen relief k. o. Koprivna z označenimi gozdnimi združbami in lokacijami ter številkami ploskev (LIDAR, 2015; ZGS, 2020)

2019 s Presslerjevim svedrom z notranjim premerom $5 \mathrm{~mm}$. Pri terenskem delu smo na ploskvah naključno izbrali drevesa v zgornjem sloju. Naključno izbiranje dreves smo izpeljali tako, da smo ploskve enakomerno razdelili na četrtine in $\mathrm{v}$ vsaki četrtini analizirali eno do dve drevesi v zgornjem sloju. Na teh drevesih smo pridobili izvrtke za dendrokronološko analizo.

Fig. 2: Shaded relief of the Koprivna cadastral municipality with marked phytosociological communities, locations and plot numbers (LIDAR, 2015; ZGS, 2020)

Izvrtke smo pridobili iz treh lokacij ploskev, in sicer iz skupin ploskev Janšek in Čofatija ter na ploskvi Zdovc 11. Ostalo skupino ploskev Zdovc smo izpustili zaradi majhne skupne površine in majhnega števila dreves v zgornjem sloju. Na ploskvah Janšek in Čofatija smo pridobili izvrtke 20 dreves smreke, na ploskvi Zdovc 11 pa izvrtke 10 dreves smreke in 10 dreves ma-

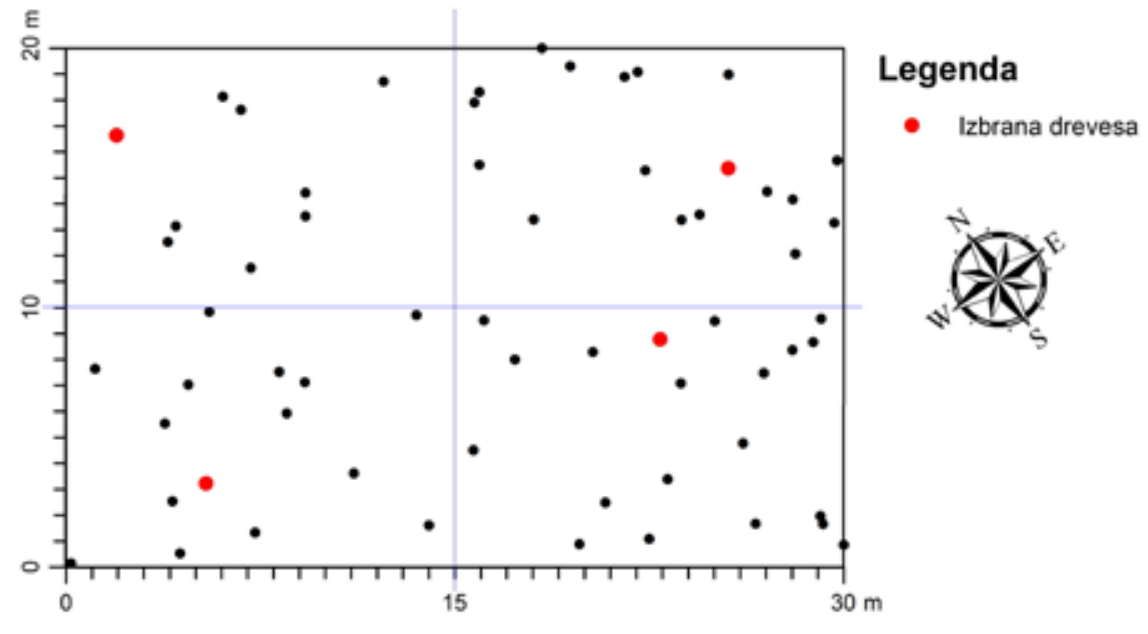

Slika 3: Razporeditev dreves na ploskvi Čofatija 3 z označenimi izbranimi drevesi, na katerih smo pridobili izvrtke za dendrokronološko analizo
Fig. 3: Position of trees on the Čofatija 3 plot with marked selected trees on which we obtained cores for dendrochronological analysis 
Preglednica 1: Osnovni podatki o raziskovalnih ploskvah in število pridobljenih izvrtkov dreves za dendrokronološko analizo (Golob, 2018)

\begin{tabular}{|c|c|c|c|c|c|c|}
\hline \multicolumn{2}{|c|}{ Ploskev } & \multirow{2}{*}{ Nadmorska višina (m) } & \multirow{2}{*}{ Ekspozicija } & \multirow{2}{*}{ Naklon terena (\%) } & \multirow{2}{*}{ Površina $\left(m^{2}\right)$} & \multirow{2}{*}{$\begin{array}{c}\text { Število izvrtkov smreke in } \\
\text { macesna* }\end{array}$} \\
\hline Št. & Kraj & & & & & \\
\hline 3 & Čofatija & 1210 & $\mathrm{~J}$ & 67 & 600 & 5 \\
\hline 4 & Čofatija & 1230 & $\mathrm{~J}$ & 67 & 400 & 5 \\
\hline 6 & Čofatija & 1250 & JJZ & 70 & 180 & 5 \\
\hline 7 & Čofatija & 1300 & JJV & 60 & 100 & 5 \\
\hline 8 & Zdovc & 1310 & SV & 60 & 100 & I \\
\hline 9 & Zdovc & 1310 & SV & 60 & 100 & 1 \\
\hline 10 & Zdovc & 1320 & SV & 40 & 49 & 1 \\
\hline 11 & Zdovc & 1300 & SSV & 57 & 2800 & $10 / 10^{*}$ \\
\hline 12 & Janšek & 1100 & SSV & 0 & 238 & 4 \\
\hline 13 & Janšek & 1170 & VSV & 55 & 262 & 4 \\
\hline 14 & Janšek & 1160 & VSV & 35 & 275 & 4 \\
\hline 15 & Janšek & 1110 & SV & 60 & 190 & 4 \\
\hline 16 & Janšek & 1120 & $\mathrm{~S}$ & 42 & 240 & 4 \\
\hline
\end{tabular}

cesna. Na vsakem izbranem drevesu smo odvzeli dva izvrtka zaradi uskladitve kronologij.

Podrobneje je trajne raziskovalne ploskve opisal Golob (2018). V preglednici 1 so opisani osnovni podatki o raziskovalnih ploskvah in številu pridobljenih izvrtkov dreves za dendrokronološko analizo.

\subsection{Analiza zaporednih meritev}

2.1 Analysis of successive measurements

Na podlagi preteklih meritev smo za leta 1962, 1972, 1990 in 2017 izračunali srednjetemeljnični premer $\left(d_{g}\right)$, dominantni premer $\left(d_{d o m}\right)$, dominantno višino $\left(h_{d o m}\right)$, število dreves na hektar $(N /$ ha), indeks sestojne gostote (SDI) in temeljnico (G). Dominantni premer smo izračunali po določilih, da ga predstavlja 100 najdebelejših dreves na hektar. Iz temeljnice smo nato izpeljali srednjetemeljnični premer za 100 najdebelejših dreves na hektar. Sestojne gostote smo izračunali na podlagi Reinekejevega indeksa sestojne gostote (SDI) (Reineke, 1933, cit. po Pretzsch in Biber, 2005) po obrazcu:

$$
\mathrm{SDI}=N(25 / d)^{-1,605}
$$

Vrednost $N$ ponazarja število dreves na hektar, vrednost $d$ pa srednjetemeljnični premer dreves na opazovani ploskvi.

Izračunali smo tudi lesno zalogo za skupine ploskev. Lesno zalogo smo izračunali po tarifah in tudi po deblovnicah za debeljad, ki jih je v analitično obliko preoblikoval Puhek (Kušar in sod., 2013). Na teh ploskvah so opravili meritve tudi v letih 1965 in 1968, vendar smo jih pri analizi izpustili, ker so bile opravljene le tri leta po predhodnih meritvah. Ploskev Zdovc 11 smo analizirali posebej, ker je bil na tej ploskvi mešan sestoj
Table 1: Basic data on research plots and the number of obtained tree cores for dendrochronological analysis (Golob, 2018)

smreke in macesna leta 1962 že dobro razvit, drevesom na tej ploskvi pa so ocenili za 25 let večjo starost kot na ostalih treh ploskvah na območju kmetije Zdovc (Golob in sod., 2019).

Primerjavo s Halajevimi tablicami (Kotar, 2007) in tudi švicarskimi tablicami (Kotar, 1980) smo naredili tako, da smo ob poznavanju dominantne višine dreves in starosti sestojev iz grafikona, ki prikazuje razvoj zgornje višine, ugotovili bonitetni razred. Pri švicarskih tablicah smo določili bonitetne razrede na podlagi starosti 50 let, pri Halajevih tablicah pa na podlagi starosti 100 let (Kotar, 1998). Proizvodno sposobnost rastišča smo ocenili tako, da smo v donosnih tablicah poiskali maksimalni povprečni volumenski prirastek $\left(\mathrm{MAI}_{\mathrm{MAKS}}\right)$. Tablični sestoj je model gospodarjenega sestoja, $\mathrm{v}$ katerem se temeljnica giblje med naravno in kritično, zato smo MAI ${ }_{\text {MAKS }}$ delili z 0,95 (Kotar, 2007) in tako ocenili volumenski prirastek debeljadi brez skorje. Dobljena vrednost ponazarja proizvodno sposobnost rastišča.

Pri primerjavi sestojnih parametrov s Halajevimi tablicami, ki jih je priredil Kotar (2007), smo za ploskve Čofatija in Zdovc določili 30. bonitetni razred in 2. raven proizvodnosti. Na ploskvi 11 pri Zdovcu smo določili 32 . bonitetni razred in 2 . raven proizvodnosti, na ploskvah pri Janšku pa 34. bonitetni razred in 2. raven proizvodnosti. Prav tako smo primerjali sestojne parametre s švicarskimi sestojnimi tablicami. Za ploskve Čofatija in Zdovc smo določili 18. bonitetni razred. Pri ploskvi 11 pri Zdovcu smo določili 20. bonitetni razred, pri ploskvah Janšek pa 22. bonitetni razred.

Zaradi poznavanja premera in višine posameznega drevesa ob vseh meritvah smo lahko izračunali povprečni letni debelinski in višinski prirastek posameznega drevesa v obdobju med meritvami. Izračunali 
smo povprečne letne debelinske in višinske prirastke dreves po posameznih ploskvah in tudi po posameznih skupinah ploskev. Na podlagi klasifikacije IUFRO smo izračunali povprečne letne debelinske in višinske prirastke dreves v zgornjem, srednjem in spodnjem sloju. Pri izračunu povprečnih letnih debelinskih in višinskih prirastkov po posameznih slojih smo upoštevali slojevitost dreves ob drugi meritvi. Razlike med povprečnimi debelinskimi prirastki dreves $\mathrm{v}$ treh slojih smo primerjali $\mathrm{z}$ analizo variance (ANOVA) in Welchevim testom.

$\mathrm{V}$ predhodnem raziskovanju smo podrobneje analizirali razlike med volumni dreves, izračunanimi na podlagi tarif in dvovhodnih deblovnic. V zadnjih meritvenih obdobjih smo za smreko ocenili pomik višinskih krivulj, kar je vplivalo na povečevanje tarifnih nizov v enomernih sestojih (Golob, 2018). Volumenske prirastke smo zato izračunali na podlagi tarif in dvovhodnih deblovnic, ker bi jih le na podlagi izračuna po naraščajočih tarifah v mlajših sestojih precenjevali (Čokl, 1971; Hladnik in Levanič, 2021).

Za drevesa, ki so med dvema meritvama odmrla, smo privzeli, da so drevesa živela do polovice obdobja med obema meritvama. Na podlagi teh premerov in višin smo nato po tarifah in deblovnicah izračunali lesno zalogo odmrlih dreves.

Neto prirastek lesne zaloge smo ob poznavanju lesne zaloge ob prvi in drugi meritvi izračunali po obraz$\mathrm{cu}$ :

$$
i_{v}=V_{2}+V_{p}-V_{1}
$$

Vrednost $V_{2}$ je lesna zaloga ob koncu meritvenega obdobja, vrednost $V_{p}$ volumen posekanih dreves in vrednost $V_{1}$ lesna zaloga na začetku meritvenega obdobja. Bruto prirastek začetne lesne zaloge smo izračunali po obrazcu:

$$
i_{v}=V_{2}+V_{m}+V_{p}-V_{1}
$$

Vrednost $V_{2}$ je lesna zaloga ob koncu meritvenega obdobja, vrednost $V_{m}$ je volumen odmrlih dreves, vrednost $V_{p}$ volumen posekanih dreves in vrednost $V_{1}$ lesna zaloga na začetku meritvenega obdobja.

Za posamezne skupine ploskev smo ocenili intenzivnost priraščanja lesne zaloge in povprečno intenzivnost priraščanja smreke na teh ploskvah. Z razmerjem med periodičnim prirastkom in lesno zalogo stoječih dreves ocenjujemo izkoristek lesne zaloge v gospodarskih gozdovih in preverjamo učinke redčenj (Diaci, 1992). V prirastoslovnih raziskavah med temeljne alo- metrične kazalce uvrščajo razmerje med povprečnim priraščanjem in povprečnim volumnom dreves $\left(i_{v} / v\right)$ na začetku meritvenega obdobja (Pretzcsh in sod., 2018). Na podlagi tega razmerja smo lahko primerjali rast smreke na raziskovalnih ploskvah Koprivne s primerljivimi raziskovanji smreke v gospodarskih gozdovih. Iz podatkov o razvoju tabličnih sestojev smo lahko ocenili intenzivnost priraščanja lesne zaloge in za enako dolga obdobja, kot so bila na Koprivni v meritvah po letu 1990. Razlike smo primerjali s t-testom.

\subsection{Analiza izvrtkov}

\subsection{Analysis of tree cores}

V dendrokronološkem laboratoriju na Gozdarskem inštitutu Slovenije smo izvrtke osušili, jih prilepili na lesene nosilce ter jih zbrusili. Izvrtke smo brusili v več korakih, pri čemer smo stopnjevali zrnatost brusnega papirja od bolj grobe do finejše. Po brušenju smo izvrtke zajeli s sistemom ATRICS (Advanced Tree-Ring Image Capturing System; Levanič, 2007). Merjenje širin branik smo opravili v programu CooRecorder (Cybis Elektronik ..., 2019).

Analizo kakovosti opravljenih meritev širin branik in iskanje morebitnih napak pri merjenju smo naredili v programu CDendro (Cybis Elektronik ..., 2019). Sledila je analiza izmerjenih zaporedij širine branik v programu PAST-5 (Knibbe, 2018). Najprej smo v tem programu preverili in povprečili oba izvrtka iz istega drevesa in tako dobili povprečno kronologijo za posamezno drevo. Sledilo je združevanje povprečnih kronologij posameznih dreves glede na skupino ploskev. Tako smo dobili povprečno kronologijo dreves za posamezno skupino ploskev.

Standardizacijo in analizo vpliva klime smo naredili v programskem okolju R (R Core Team, 2020) in uporabili knjižnici za standardizacijo dendrokronoloških krivulj (dplR) in izračun korelacije med standardiziranimi širinami branik in klimatskimi podatki (treeclim). Standardizacijo krivulje smo opravili zato, da smo s pomočjo statističnega filtriranja iz zaporedij širin branik odstranili kar največ dejavnikov, ki niso povezani z vplivom klime na rast dreves, in tako dobili krivuljo, ki dobro kaže vpliv klime na rast dreves. Pri analizi vpliva klime na debelinsko priraščanje smo podatke o padavinah in temperaturi pridobili v bazi e-Obs verzija 20.0 s prostorsko resolucijo $0,25 \times 0,25$ stopinje oziroma $27,75 \times 27,75 \mathrm{~km}$ za klimatsko celico E14,50 - 14,75 in N46,25 - 46,50 za obdobje 1950-2019 (The Copernicus ..., 2020).

Za predstavitev rezultatov o vplivu klime na debelinsko priraščanje smo uporabili tri grafične prikaze. 
Na prvem smo predstavili standardno kronologijo, ki vsebuje avtokorelacijo, in rezidualno kronologijo, ki avtokorelacije nima (slika 4).

Na drugem prikazu je predstavljena enostavna Pearsonova korelacija, za katero smo intervala zaupanja izračunali s t.i. bootstrapped metodo. Korelacija nam pove, s katerim parametrom določenega meseca lahko najbolje pojasnimo variacije v širini branike (slika 6). Na tretjem grafičnem prikazu pa smo predstavili odziv širine branike na klimo po obdobjih (slika 7). Podobno kot pri enostavni korelaciji gre tudi tukaj za Pearsonovo bootstrapped korelacijo, le da je bila izračunana za obdobja po 25 let s korakom naprej po eno leto. $\mathrm{Za}$ vsak slikovni element oziroma kvadratek na sliki so bile po 1000-krat izračunane korelacije za naključno izbrane kombinacije širin branik in podatkov klime v oknu širine 25 let. Ta tehnika zagotovi, da lahko izračunamo povprečje korelacijskega koeficienta in standardni odklon, ker imamo 1000 izračunov korelacije. Če kvadratek vsebuje zvezdico, to pomeni, da je ta kombinacija značilna.

Posebej smo izdelali tudi analizo značilnih let, to je tistih let, v katerih ima večina dreves enak odziv. Zna- čilna leta kažejo na prirastni odziv dreves v klimatsko ali za rast kako drugače posebnih letih. Kadar v kronologijah zabeležimo enoten odziv na določeno leto, to pomeni, da je v tistem letu na rast dreves vplival neki ključen okoljski ali fiziološki dejavnik. Med pomembne okoljske dejavnike štejemo klimatske ekstreme (vroča/suha poletja ali hladna/mokra poletja), med fiziološke pa npr. semenska leta, napade škodljivcev in podobno.

0 pozitivnih značilnih letih govorimo, ko ima večina dreves povečan prirastek v primerjavi s predhodnim letom. Nasprotno pa govorimo o negativnih značilnih letih, ko ima večina dreves manjši prirastek v primerjavi s predhodnim letom. Šibka negativna oziroma pozitivna leta so tista, $v$ katerih je enak odziv pokazalo $75 \%$ dreves. Močna negativna oziroma pozitivna leta so tista, v katerih je enak odziv pokazalo $90 \%$ dreves. Za preučevanje vpliva klime na rast dreves so pomembna tista leta, kjer je imelo enak odziv več skupin ploskev. Za pomembna značilna leta smo vzeli tista, $v$ katerih je bil enak odziv ocenjen na 2 od 3 ploskev.
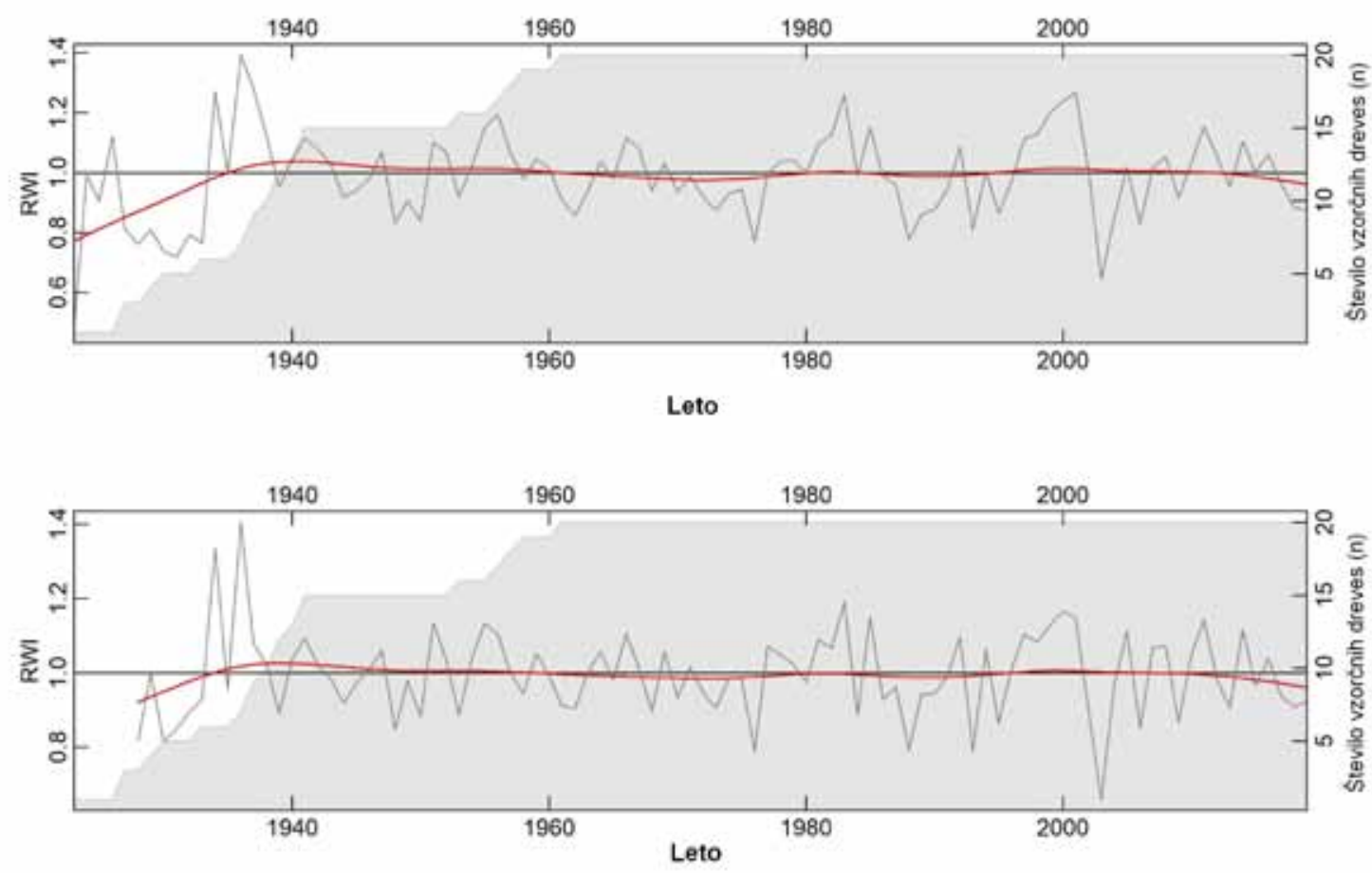

Slika 4: Standardna (zgoraj) in rezidualna (spodaj) kronologija na ploskvah Čofatije. Indeks širine branik RWI (ringwidth index) ponazarja razliko med dejanskimi širinami branik in prilagojenimi vrednostmi na kubičnem zlepku. Z rdečo krivuljo je predstavljeno nihanje, ki pokaže, ali so v obeh kronologijah ostala velika nihanja. Sivo polje ponazarja število dreves v vzorcu, uporabljenih za izračun kronologije.
Fig. 4: Standard (above) and residual (below) chronology on the Čofatija plots. The RWI (ring-width index) represents the difference between the actual widths and the adjusted values on the cubic spline. The red curve represents the oscillation, which shows whether large oscillations remained in both chronologies. The gray area represents the number of trees in the sample used to calculate the chronology. 


\section{REZULTATI}

\section{RESULTS}

\subsection{Sestojni parametri in primerjava s sestojni- mi tablicami}

3.1 Stand parameters and comparison with yield tables

Od prve meritve v letu 1962 pa vse do zadnje meritve v letu 2017 se je srednjetemeljnični premer dreves na ploskvah pri Čofatiji povečal za trikrat, srednjetemeljnični premer smreke na ploskvi 11 pri Zdovcu pa je bil 2,5-krat večji kot pri prvem merjenju (preglednica 2). V mlajših sestojih na ploskvah pri Janšku je srednjetemeljnični premer presegel $10 \mathrm{~cm} v$ obdobju do leta 1990, na ploskvah pri Zdovcu pa šele v zadnjem meritvenem obdobju do leta 2017.

V obdobju od prve do zadnje meritve se je število dreves na ploskvah pri Čofatiji zmanjšalo za 78,3 \%, pri Janšku za 88,4 \% in na ploskvah pri Zdovcu za 95,9 \%. Nihanja v oceni SDI so bila na ploskvah pri Čofatiji majhna, na ploskvah pri Zdovcu in Janšku pa so bila ob veliki mortaliteti tudi posledica vraščanja novih mladih dreves smreke vse do leta 1990 . V letu 2017 so bile ob manjših srednjetemeljničnih premerih sestojne te-

Preglednica 2: Sestojni parametri na štirih skupinah ploskev na območju Koprivne in primerjava s Halajevimi in švicarskimi tablicami meljnice večje od tabličnih, le na ploskvah pri Janšku so dosegle $92 \%$ sestojne temeljnice v primerjavi s prirejenimi Halajevimi tablicami donosov (preglednica 2). Večjo sestojno gostoto smo ocenili tudi na podlagi ocene SDI, ki je po Halajevih tablicah ob koncu opazovanja dosegel največjo vrednost 1014 za bonitetni razred 30 oziroma vrednost 1024 za bonitetni razred 34 . Na ploskvi Zdovc 11 je bil leta 2017 mešan sestoj smreke in macesna, zato smo v ločeni preglednici prikazali sestojne parametre za obe drevesni vrsti (preglednica 3). Ta sestoj je bil ob začetku opazovanja že v razvojni fazi drogovnjaka z dominantnimi drevesi macesna. Po letu 1990 je bila mortaliteta smreke (51\% dreves) in macesna (36 \%) še visoka, o čemer priča tudi zmanjšanje skupne temeljnice smreke in zmanjšanje kazalca SDI za 13 \% do zadnje meritve v letu 2017.

Na ploskvah pri Čofatiji je lesna zaloga, izračunana po dvovhodnih deblovnicah za debeljad, za od 5 do $7 \%$ večja kot lesna zaloga, izračunana po tarifah (preglednica 4). Na drugih ploskvah so razlike v zadnjih obdobjih manjše od $5 \%$, na začetku meritvenih obdobij do leta 1972 pa so bile lesne zaloge pri Zdovcu in Janšku po deblovnicah večje za $12 \%$. Na ploskvah pri Zdov-

Table 2: Stand parameters on four groups of plots in Koprivna and comparison with Halaj and Swiss yield tables

\begin{tabular}{|c|c|c|c|c|c|c|c|c|c|c|c|c|c|c|c|c|c|}
\hline \multirow{2}{*}{ Ploskve } & \multirow{2}{*}{ Leto } & \multirow{2}{*}{\begin{tabular}{|c|}
$\begin{array}{c}\text { Starost } \\
\text { sestojev } \\
\text { (let) }\end{array}$ \\
\end{tabular}} & \multicolumn{7}{|c|}{ Raziskovalne ploskve } & \multicolumn{4}{|c|}{ Halajeve tablice } & \multicolumn{4}{|c|}{ Švicarske tablice } \\
\hline & & & $d_{g}$ & $d_{d o m}$ & $h_{\text {dom }}$ & $\mathrm{n}$ & N/ha & SDI & G $\left(\mathrm{m}^{2} / \mathrm{ha}\right)$ & $d_{g}$ & $d_{d o m}$ & $\mathrm{~N} / \mathrm{ha}$ & $G\left(\mathrm{~m}^{2} / \mathrm{ha}\right)$ & $d_{g}$ & $d_{d o m}$ & N/ha & $G\left(m^{2} / h a\right)$ \\
\hline \multirow{4}{*}{ Čofatija } & 1962 & 47 & 9,0 & 25,9 & 16,3 & 796 & 6.219 & 1216 & 39,64 & 16,3 & 17,7 & 1956 & 40,70 & 15,1 & 16,7 & 1549 & 27,87 \\
\hline & 1972 & 57 & 12,3 & 29,7 & 19,1 & 444 & 3.499 & 1126 & 41,83 & 20,1 & 21,0 & 1421 & 45,02 & 18,9 & 20,5 & 1083 & 30,41 \\
\hline & 1990 & 75 & 15,7 & 37,1 & 25,2 & 340 & 2.655 & 1262 & 51,57 & 26,2 & 25,6 & 936 & 50,60 & 25,6 & 25,4 & 641 & 33,10 \\
\hline & 2017 & 102 & 27,2 & 46,2 & 30,4 & 173 & 1.352 & 1286 & 61,67 & 33,9 & 30,3 & 622 & 56,12 & 35,8 & 30,4 & 349 & 5,18 \\
\hline \multirow{4}{*}{ Zdovc } & 1962 & 17 & 1,6 & 7,4 & 4,3 & 1.158 & 46.344 & 580 & 9,69 & 1 & 1 & 1 & 1 & I & 1 & 1 & 1 \\
\hline & 1972 & 27 & 3,7 & 15,7 & 10,5 & 573 & 22.931 & 1075 & 2484 & 7,8 & 8,4 & 5489 & 25,9 & I & 1 & 1 & 1 \\
\hline & 1990 & v & 9,2 & 22,2 & 16,1 & 193 & 7.750 & 1545 & $\pi$ & 15,5 & 17,0 & 2093 & 39,7 & 14,4 & 15,9 & 1682 & 27,25 \\
\hline & 2017 & 72 & 19,0 & 32,4 & 25,2 & 47 & 1.880 & 1215 & 53,60 & 25,3 & 24,9 & 995 & 49,82 & 25,3 & 24,7 & 691 & 32,80 \\
\hline \multirow{4}{*}{ Janšek } & 1962 & 32 & 5,5 & 23,0 & 15,4 & 1505 & 12.438 & 1106 & 29,94 & 12,1 & 14,2 & 3044 & 35,20 & 12,1 & 13,16 & 2199 & 26,20 \\
\hline & 1972 & 42 & 8,4 & 28,8 & 18,7 & 810 & 6.698 & 1155 & 36,78 & 16,9 & 19,3 & 1863 & 41,92 & 17,8 & 18,32 & 1414 & 31,22 \\
\hline & 1990 & 60 & 11,1 & 32,2 & 21,2 & 460 & 3.799 & 1033 & 36,80 & 24,7 & 25,7 & 1042 & 49,9 & 24,7 & 25,6 & 739 & 36,00 \\
\hline & 2017 & 87 & 21,8 & 46,6 & 31,9 & 174 & 1.438 & 1157 & 52,53 & 34,2 & 31,9 & 619 & 56,9 & 34,2 & 31,93 & 369 & 39,12 \\
\hline
\end{tabular}

Preglednica 3: Sestojni parametri na ploskvi Zdovc 11 na

Table 3: Stand parameters on plot Zdovc 11 in Koprivna območju Koprivne

\begin{tabular}{|c|c|c|c|c|c|c|c|c|c|c|c|c|}
\hline \multirow{2}{*}{ Leto } & \multirow{2}{*}{$\begin{array}{c}\text { Starost } \\
\text { sestojev } \\
\text { (let) }\end{array}$} & \multicolumn{2}{|c|}{$d_{g}$} & \multicolumn{2}{|c|}{$d_{d o m}$} & \multicolumn{2}{|c|}{$\boldsymbol{h}_{\text {dom }}$} & \multicolumn{2}{|c|}{$\mathbf{G}\left(\mathrm{m}^{2} / \mathrm{ha}\right)$} & \multicolumn{3}{|c|}{ Skupaj } \\
\hline & & smreka & macesen & smreka & macesen & smreka & macesen & smreka & macesen & $\mathrm{N} / \mathrm{ha}$ & $G\left(\mathrm{~m}^{2} / \mathrm{ha}\right)$ & SDI \\
\hline 1962 & 42 & 12,0 & 23,3 & 27,6 & 32,2 & 20,6 & 23,8 & 16,92 & 17,61 & 2051 & 36,63 & 911 \\
\hline 1990 & 70 & 20,7 & 32,6 & 36,9 & 42,9 & 27,4 & 33,7 & 22,33 & 27,41 & 996 & 50,01 & 1014 \\
\hline 2017 & 97 & 29,7 & 40,9 & 41,3 & 48,2 & 31,6 & 37,8 & 20,68 & 28,08 & 532 & 48,68 & 878 \\
\hline
\end{tabular}


Preglednica 4: Spreminjanje lesne zaloge in lesne zaloge z všteto mortaliteto na štirih skupinah ploskev na območju Koprivne v obdobju meritev in primerjava s Halajevimi in švicarskimi tablicami
Table 4: Changes in growing stock and growing stock with included mortality on four groups of plots in Koprivna during the measurement periods and comparison with Halaj and Swiss yield tables

\begin{tabular}{|c|c|c|c|c|c|c|c|c|}
\hline \multirow{3}{*}{ Ploskve } & \multirow{3}{*}{ Leto } & \multirow{3}{*}{$\begin{array}{c}\text { Starost } \\
\text { sestojev } \\
\text { (let) }\end{array}$} & \multicolumn{4}{|c|}{ Raziskovalne ploskve } & \multirow{3}{*}{$\begin{array}{c}\begin{array}{c}\text { Halajeve } \\
\text { tablice }\end{array} \\
\mathrm{V}\left(\mathrm{m}^{3} / \mathrm{ha}\right)\end{array}$} & \multirow{3}{*}{$\begin{array}{c}\begin{array}{c}\text { Švicarske } \\
\text { tablice }\end{array} \\
\left.\text { V ( } \mathrm{m}^{3} / \mathrm{ha}\right)\end{array}$} \\
\hline & & & \multicolumn{2}{|r|}{ V } & \multicolumn{2}{|c|}{$V+V m$} & & \\
\hline & & & tarife $\left(\mathrm{m}^{3} / \mathrm{ha}\right)$ & deblovnice (m³/ha) & tarife (m $\left.{ }^{3} / \mathrm{ha}\right)$ & deblovnice ( $\left.\mathrm{m}^{3} / \mathrm{ha}\right)$ & & \\
\hline \multirow{4}{*}{ Čofatija } & 1962 & 47 & 216,91 & 232,39 & 1 & 1 & 298,8 & 178,9 \\
\hline & 1972 & 57 & 288,54 & 302,48 & 328,68 & 341,84 & 388,8 & 257,5 \\
\hline & 1990 & 75 & 456,38 & 489,88 & 507,26 & 540,42 & 527,0 & 363,5 \\
\hline & 2017 & 102 & 682,70 & 724,11 & 796,77 & 856,62 & 686,0 & 464,6 \\
\hline \multirow{4}{*}{ Zdovc } & 1962 & 17 & 1 & 1 & 1 & 1 & 1 & 1 \\
\hline & 1972 & 27 & 1 & 35,19 & 1 & 35,62 & 100,2 & 1 \\
\hline & 1990 & 45 & 292,31 & 305,16 & 298,03 & 311,89 & 280,0 & 161,5 \\
\hline & 2017 & 72 & 566,41 & 547,10 & 720,72 & 650,52 & 506,0 & 358,6 \\
\hline \multirow{3}{*}{ Zdovc 11} & 1962 & 42 & 293,02 & 334,14 & 293,02 & 334,14 & 294,6 & 237,6 \\
\hline & 1990 & 70 & 622,35 & 651,17 & 702,11 & 709,02 & 556,0 & 403,0 \\
\hline & 2017 & 97 & 761,30 & 738,49 & 922,42 & 873,31 & 733,2 & 520,5 \\
\hline \multirow{4}{*}{ Janšek } & 1962 & 32 & 122,84 & 139,87 & 122,84 & 139,87 & 215,6 & 112,6 \\
\hline & 1972 & 42 & 213,88 & 230,51 & 228,44 & 245,51 & 339,2 & 228,2 \\
\hline & 1990 & 60 & 275,77 & 262,72 & 424,98 & 426,34 & 530,0 & 403,0 \\
\hline & 2017 & 87 & 623,85 & 635,15 & 745,81 & 708,85 & 743,2 & 552,1 \\
\hline
\end{tabular}

cu so drevesa v prvih obdobjih šele preraščala merski prag $10 \mathrm{~cm}$ in so bila zaradi tega prvič upoštevana pri izračunu in primerjavi lesne zaloge v letu 1990.

Razlika med lesno zalogo in lesno zalogo z všteto mortaliteto se je skozi obdobja meritev povečevala in je ob zadnji meritvi znašala $20 \%$.

\subsection{Volumenski in temeljnični prirastek sestojev}

3.2 Volume and basal area increment of forest stands

Pri primerjavi neto in bruto prirastka lesne zaloge opazimo, da so bruto prirastki lesne zaloge večji za več kot $30 \%$ kot neto prirastki lesne zaloge (preglednica 5). Pri ploskvi 11 pri Zdovcu in ploskvah pri Janšku smo v prvem obdobju zaznali največji temeljnični prirastek, in sicer $0,48 \mathrm{~m}^{2} / \mathrm{ha}$ /leto oziroma $0,68 \mathrm{~m}^{2} / \mathrm{ha}$ /leto.

Prirastek temeljnice skozi celotno obdobje se na vseh skupinah ploskev giblje med $0,22 \mathrm{~m}^{2} / \mathrm{ha}$ /leto in $0,80 \mathrm{~m}^{2} / \mathrm{ha} /$ leto. Povprečni prirastek lesne zaloge na leto od prve meritve leta 1962 pa do zadnje meritve leta 2017 se na vseh skupinah ploskev giblje med $8,47 \mathrm{~m}^{3}$ /ha/leto in $10,30 \mathrm{~m}^{3} /$ ha/leto, izračunan po tarifah, oziroma med 7,35 $\mathrm{m}^{3} / \mathrm{ha}$ /leto in $9,95 \mathrm{~m}^{3} / \mathrm{ha}$ /leto, izračunan po deblovnicah. Bruto prirastki lesne zaloge so na ploskvah s prevladujočo smreko višji od tabličnih vrednosti.

Proizvodna sposobnost na ploskvah pri Čofatiji in Zdovcu znaša po Halajevih tablicah 9,16 $\mathrm{m}^{3}$ /ha/leto, po švicarskih tablicah pa $8,63 \mathrm{~m}^{3}$ /ha/leto. Na podlagi Halajevih tabličnih sestojev znaša proizvodna sposobnost rastišča na ploskvi 11 pri Zdovcu za smreko 10,21 $\mathrm{m}^{3} / \mathrm{ha} /$ leto, po švicarskih tabličnih sestojih pa znaša proizvodna sposobnost rastišča za smreko $10,42 \mathrm{~m}^{3}$ /ha/leto. Na ploskvah pri Janšku znaša na podlagi Halajevih tabličnih sestojev proizvodna sposobnost rastišča za smreko $11,47 \mathrm{~m}^{3} /$ ha/leto. Na podlagi švicarskih tabličnih sestojev znaša proizvodna sposobnost rastišča za smreko $12,21 \mathrm{~m}^{3}$ /ha/leto.

Razmerje med povprečnim volumenskim prirastkom in volumnom dreves $\left(i_{v} / v\right)$ smo uporabili za primerjavo s podatki v Halajevih tablicah donosov. Ker so bila opazovalna obdobja na Koprivni dolga 18 in 27 let, smo za ponazoritev dodali ocene iz primerljivih raziskovalnih ploskev s krajšimi opazovalnimi obdobji (slika 5).

Večje vrednosti razmerja $i_{v} / v$ smo potrdili s statističnim preizkusom, pri katerem smo upoštevali povprečne vrednosti dreves za posamezno skupino ploskev in ga primerjali $\mathrm{z}$ vrednostjo iz Halajevih tablic za enako dolga obdobja opazovanja. Za drevesa na ploskvah pri Čofatiji smo v vseh obdobjih potrdili značilno višje vrednosti $i_{v} / v$ od tabličnih $(p<0,01)$, za zadnje obdobje do leta 2017 tudi za drevesa pri Janšku $(p<0,01)$ in Zdovcu $(p<0,05)$. 
Preglednica 5: Neto in bruto volumenski prirastek sestojev $\left(i_{v}\right)$ v različnih obdobjih na štirih skupinah ploskev na območju Koprivne, izračunan po tarifah in deblovnicah ter temeljnični prirastek $\left(i_{G}\right)$
Table 5: Net and gross volume increment $\left(i_{v}\right)$ in different periods on four groups of plots in Koprivna calculated according to tariffs, two-entry volume tables and basal area increment $\left(i_{G}\right)$

\begin{tabular}{|c|c|c|c|c|c|c|c|c|}
\hline \multirow{3}{*}{ Ploskve } & \multirow{3}{*}{ Prirastek } & \multicolumn{7}{|c|}{ Obdobje } \\
\hline & & \multicolumn{2}{|c|}{$1962-1972$} & \multicolumn{2}{|c|}{ 1972-1990 } & \multicolumn{2}{|c|}{ 1990-2017 } & \multirow{2}{*}{$\frac{1962-2017}{\text { Neto }}$} \\
\hline & & Neto & Bruto & Neto & Bruto & Neto & Bruto & \\
\hline \multirow{3}{*}{ Čofatija } & $i_{v}\left(\mathrm{~m}^{3} /\right.$ ha/leto; tarife $)$ & 7,16 & 11,18 & 9,32 & 12,15 & 8,38 & 12,61 & 8,47 \\
\hline & $i_{v}\left(\mathrm{~m}^{3} /\right.$ ha/leto; debl. $)$ & 7,01 & 10,95 & 10,41 & 13,22 & 8,67 & 13,58 & 8,94 \\
\hline & $i_{G}\left(\mathrm{~m}^{2} /\right.$ ha/leto $)$ & 0,22 & & 0,54 & & 0,40 & & 0,41 \\
\hline \multirow{3}{*}{ Zdovc } & $i_{v}\left(\mathrm{~m}^{3} /\right.$ ha/leto; tarife $)$ & 1 & 1 & 1 & 1 & 10,15 & 15,87 & 10,30 \\
\hline & $i_{v}\left(\mathrm{~m}^{3} /\right.$ ha/leto; debl. $)$ & 1 & 1 & 15,00 & 15,37 & 8,96 & 12,79 & 9,95 \\
\hline & $i_{G}\left(\mathrm{~m}^{2} /\right.$ ha/leto $)$ & 1,51 & & 1,45 & & 0,10 & & 0,80 \\
\hline \multirow{6}{*}{ Janšek } & $i_{v}\left(\mathrm{~m}^{3} /\right.$ ha/leto; tarife $)$ & 9,10 & 10,56 & 3,44 & 11,73 & 12,89 & 17,41 & 9,11 \\
\hline & $i_{v}\left(\mathrm{~m}^{3} /\right.$ ha/leto; debl. $)$ & 9,06 & 10,56 & 1,79 & 10,88 & 13,79 & 16,52 & 9,01 \\
\hline & $i_{G} \mathrm{~m}^{2} /$ ha/leto & 0,68 & & 0,00 & & 0,58 & & 0,41 \\
\hline & & \multicolumn{7}{|c|}{ Obdobje } \\
\hline & & \multicolumn{4}{|c|}{$1962-1990$} & \multicolumn{2}{|c|}{ 1990-2017 } & 1962-2017 \\
\hline & & \multicolumn{2}{|c|}{ Neto } & \multicolumn{2}{|c|}{ Bruto } & Neto & Bruto & Neto \\
\hline \multirow{3}{*}{ Zdovc 11} & $i_{v}\left(\mathrm{~m}^{3} / \mathrm{ha} /\right.$ leto; tarife $)$ & \multicolumn{2}{|c|}{11,76} & \multicolumn{2}{|c|}{14,61} & 5,15 & 11,11 & 8,51 \\
\hline & $i_{v}\left(\mathrm{~m}^{3} /\right.$ ha/leto; debl. $)$ & \multicolumn{2}{|c|}{11,32} & \multicolumn{2}{|c|}{13,39} & 3,23 & 8,23 & 7,35 \\
\hline & $i_{G}\left(\mathrm{~m}^{2} /\right.$ ha/leto $)$ & \multicolumn{2}{|c|}{0,48} & & & $-0,05$ & & 0,22 \\
\hline
\end{tabular}

$i / v(\%)$

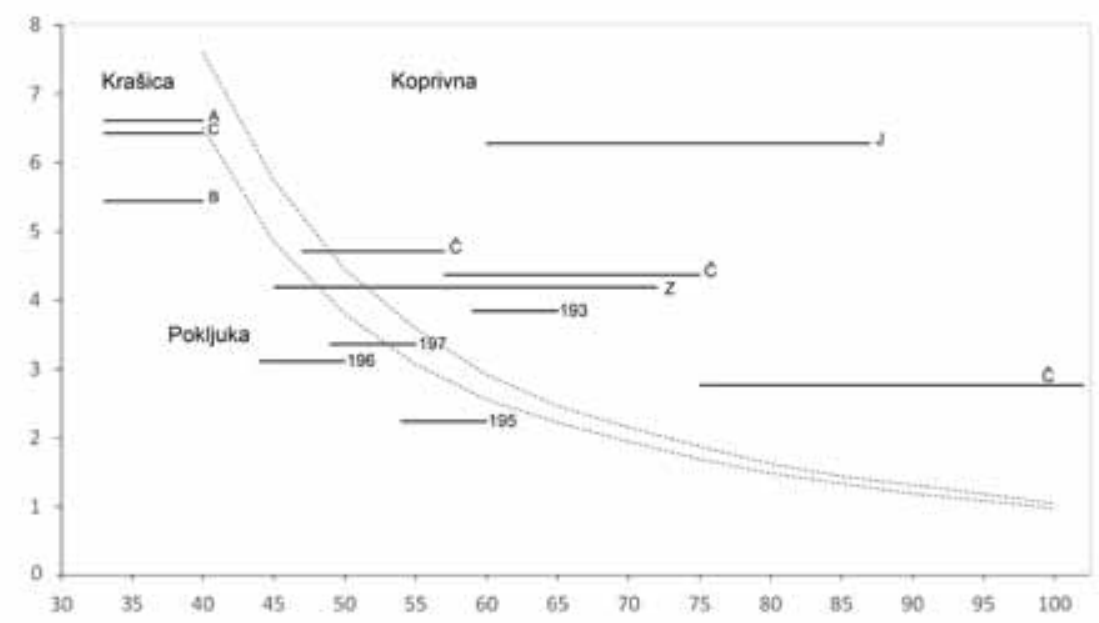

Starost (let)

Slika 5: Prikaz razmerja med periodičnim letnim volumenskim prirastkom in lesno zalogo na začetku meritvenega obdobja $\left(i_{v} / v\right)$ na raziskovalnih ploskvah v Koprivni ( $\check{C}$ - Čofatija, Z - Zdovc, J - Janšek) po starostnih obdobjih, v katerih so potekale meritve. Dolžine daljic prikazujejo dolžino starostnega obdobja, prekinjeni črti prikazujeta razmerje $i_{v} / v$, izračunano po 5-letnih obdobjih v Halajevih tablicah donosov (rastiščna indeksa 30 in 34, raven proizvodnje 2). Dodane so ocene, izračunane iz podatkov za 8-letno obdobje opazovanja smrekovih sestojev na Krašici (raziskovalne ploskve A, B, in C; Diaci, 1992) ter 6-letna obdobja na Pokljuki (ploskve 193, 195, 196 in 197; Čokl, 1971).
Fig. 5: Presentation of the ratio between periodic annual volume increment and volume at the beginning of the measurement period $\left(i_{v} / v\right)$ on research areas in Koprivna ( $\check{C}$ - Čofatija, Z - Zdovc, J - Janšek) by the age periods in which the measurements took place. The line lengths show the length of the age period, and the dashed lines show the $i_{v} / v$ ratio calculated after 5-year periods in the Halaj yield tables (Site index 30 and 34, yield level 2). Estimates calculated from the data for the 8-year observation period of spruce stands in Krašica (Research plots A, B and C; Diaci, 1992) and 6-year periods in Pokljuka (Plots 193, 195, 196 and 197; Čokl, 1971). 


\subsection{Debelinski prirastek}

\subsection{Radial increment}

Pri analizi debelinskih prirastkov po slojih smo na vseh skupinah ploskev ocenili značilne razlike $(p<0,01)$ v priraščanju med drevesi, ki so v zgornjem sloju in drevesi v srednjem in spodnjem sloju (sliki 6 in 7). V zadnjem obdobju smo ocenili značilno nižji $(p<0,01)$ prirastek smreke $v$ zgornjem sloju na ploskvah pri Čofatiji ter pri Zdovcu tudi nižji prirastek macesna $(p<0,01)$. Debelinski prirastek smreke v zgornjem sloju se je na ploskvah pri Janšku iz začetnega obdobja povečeval, vendar v zadnjih dveh obdobjih nismo ocenili značilnih razlik. Debelinsko priraščanje smreke v srednjem sloju je v vseh obdobjih za skoraj polovico manjše kot debelinsko priraščanje $\mathrm{v}$ zgornjem sloju, vendar je v srednjih in spodnjih slojih večja variabilnost v priraščanju smreke. V zgornjem sloju so koeficienti variacije za oceno debelinskega prirastka med 40 in $50 \%$, na Čofatiji tudi še v srednjem sloju. Pri Janšku v srednjem sloju že dosežejo $80 \%$, v spodnjem sloju pa presežejo $150 \%$, podobno kot smreke na Čofatiji, ker smo v spodnjem sloju ocenili koeficient variacije $127 \%$

Na ploskvi 11 pri Zdovcu (slika 7) je po letu 1990 odmrlo $36 \%$ macesnov in $51 \%$ smrek. V predzadnjem obdobju so odmrli macesni v spodnjem sloju, v zadnjem obdobju do leta 2017 pa še macesni v srednjem sloju. Socialni sestop dreves je še izraziteje ocenjen na ploskvah pri Čofatiji in Janšku (slika 6), kjer je po letu 1990 najmočneje upadel prirastek dreves v srednjem sloju, mortaliteta smreke v spodnjem sloju pa je bila 72 \% na Čofatiji in 78 \% pri Janšku.

$\mathrm{S}$ parnimi primerjavami dominantnih dreves, ki smo jim ocenili debelinski prirastek $\mathrm{z}$ izvrtki in $\mathrm{z}$ raz-
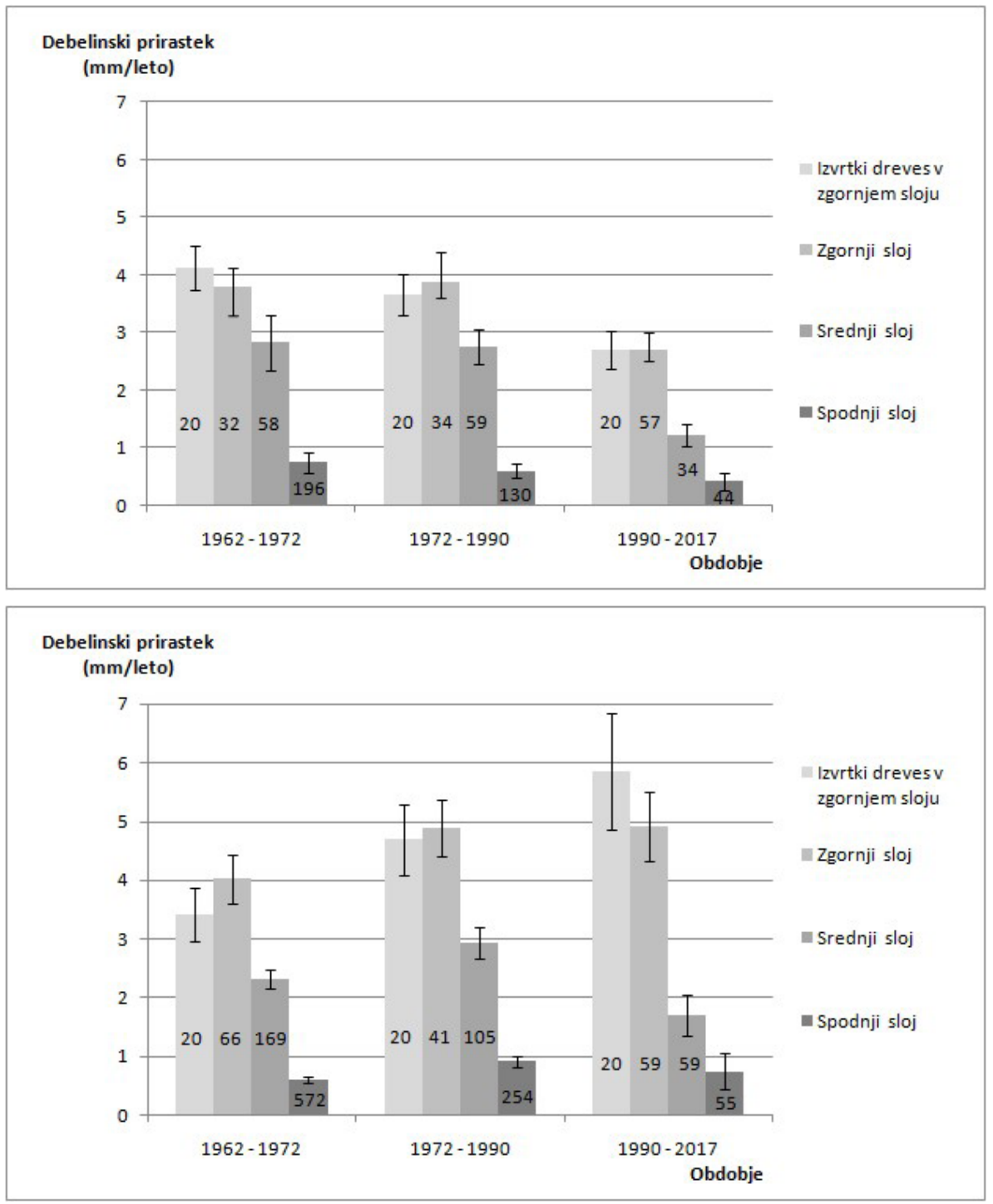

Slika 6: Debelinski prirastki smreke v različnih obdobjih na ploskvah nekdanje kmetije Čofatija (zgoraj) in kmetije Janšek (spodaj). Pri izvrtkih dreves v zgornjem sloju so predstavljene tudi intervalne ocene pri 95\% zanesljivosti.
Fig. 6: Diameter increment of spruce in different periods on the plots of the former Čofatija farm (above) and the Janšek farm (below). For tree cores in the upper layer, interval estimates at $95 \%$ reliability are also presented. 

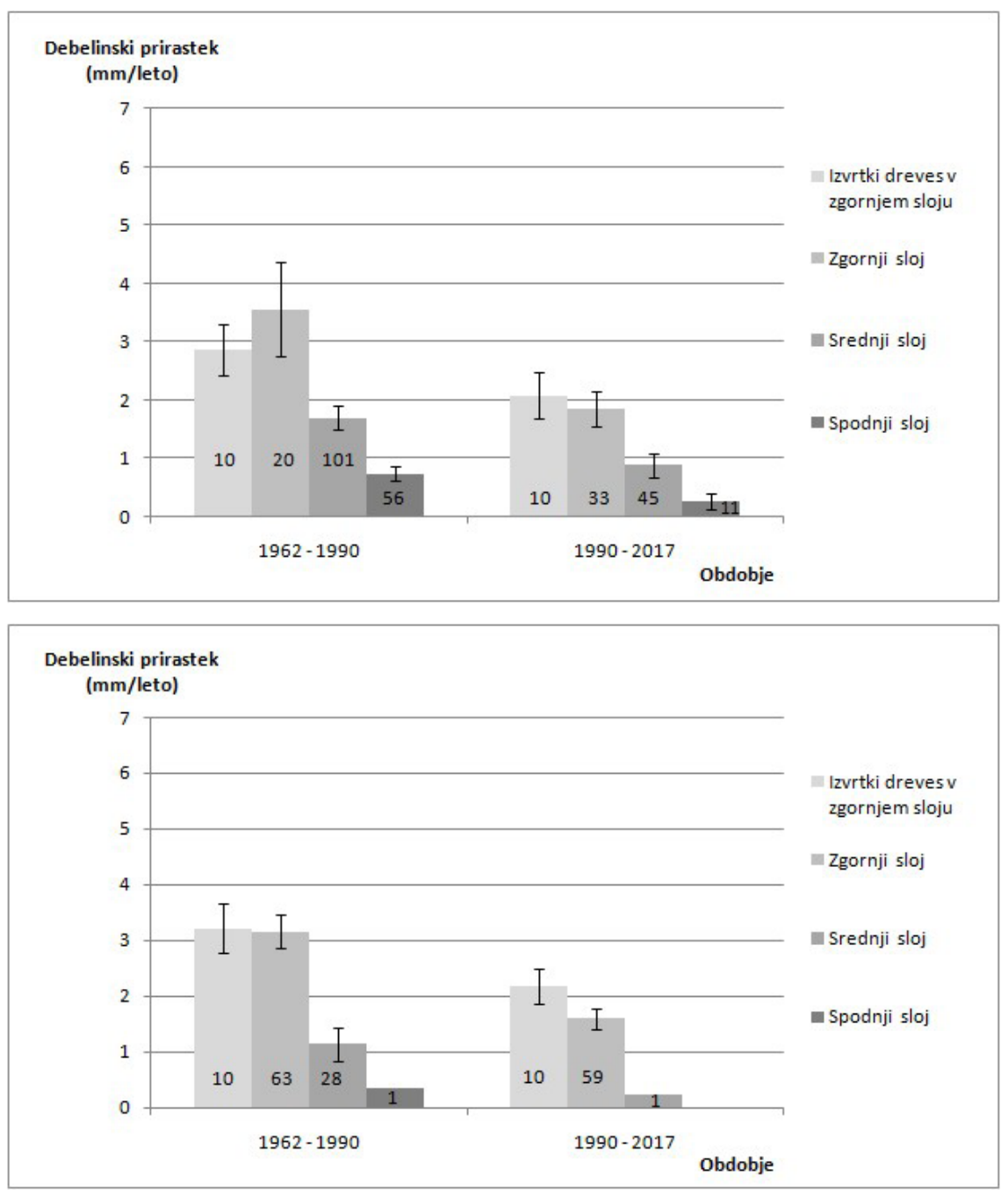

Slika 7: Debelinski prirastki smreke (zgoraj) in macesna (spodaj) v različnih obdobjih na ploskvi 11 kmetije Zdovc. Pri izvrtkih dreves v zgornjem sloju so predstavljene tudi intervalne ocene pri 95\% zanesljivosti.

liko premerov, v zadnjem obdobju nismo odkrili značilnih razlik. Vzorci 20 oziroma 10 smrek in macesnov za posamezno skupino ploskev so bili premajhni za podrobnejšo analizo in primerjavo ocen prirastkov po obeh metodah.

\subsection{Analiza vpliva klime na rast dreves}

3.4 Analysis of the impact of climate on tree growth

Za ponazoritev obsežnih analiz o vplivu klime na rast smreke in macesna na območju Koprivne prikazujemo del izsledkov iz raziskovalnih ploskev pri Zdovcu in Janšku. V obdobju od leta 1951 do leta 2019 smo z dendrokronološko analizo zaznali pozitiven vpliv nadpovprečnih temperatur v maju, ki so značilno vplivale
Fig. 7: Diameter increment of spruce (above) and larch (below) in different periods on plot 11 of the Zdovc farm. For tree cores in the upper layer, interval estimates at 95\% reliability are also presented.

na prirastek macesna na ploskvi 11 pri Zdovcu (slika 8).

V mesecu juliju je po obdobjih najbolj vidna sprememba v odzivu širine branik na povprečno temperaturo (slika 9). Temperature v tem mesecu so pozitivno, vendar neznačilno, vplivale na širino branike do obdobja 1979-2003, nato pa so temperature močno statistično negativno značilno vplivale na širino branike v zadnjih obdobjih. Pri vplivu padavin je najbolj opazna razlika v širini branik po obdobjih v juniju in juliju. Do obdobja 1975-1999 je bil odziv širine branik na padavine $v$ tem mesecu negativen, vendar neznačilen, $v$ nasprotju z zadnjimi obdobji, kjer je odziv širine branike na padavine statistično značilno pozitiven. 


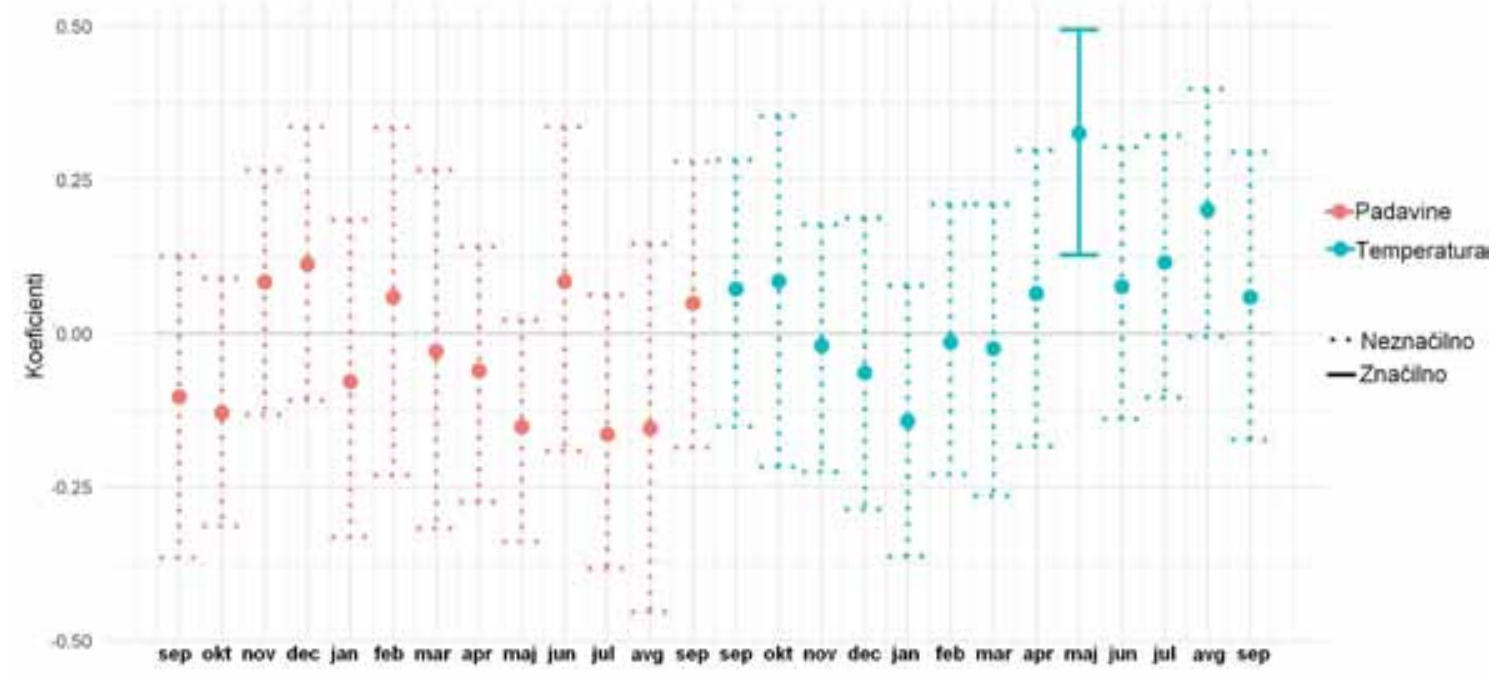

Slika 8: Vpliv padavin in povprečnih temperatur na prirastke macesna na ploskvi 11 pri Zdovcu obdobju od leta 1951 do leta 2019

Fig. 8: Influence of precipitation and average temperatures on larch radial increment on plot 11 near the Zdovc farm in the period from 1951 to 2019

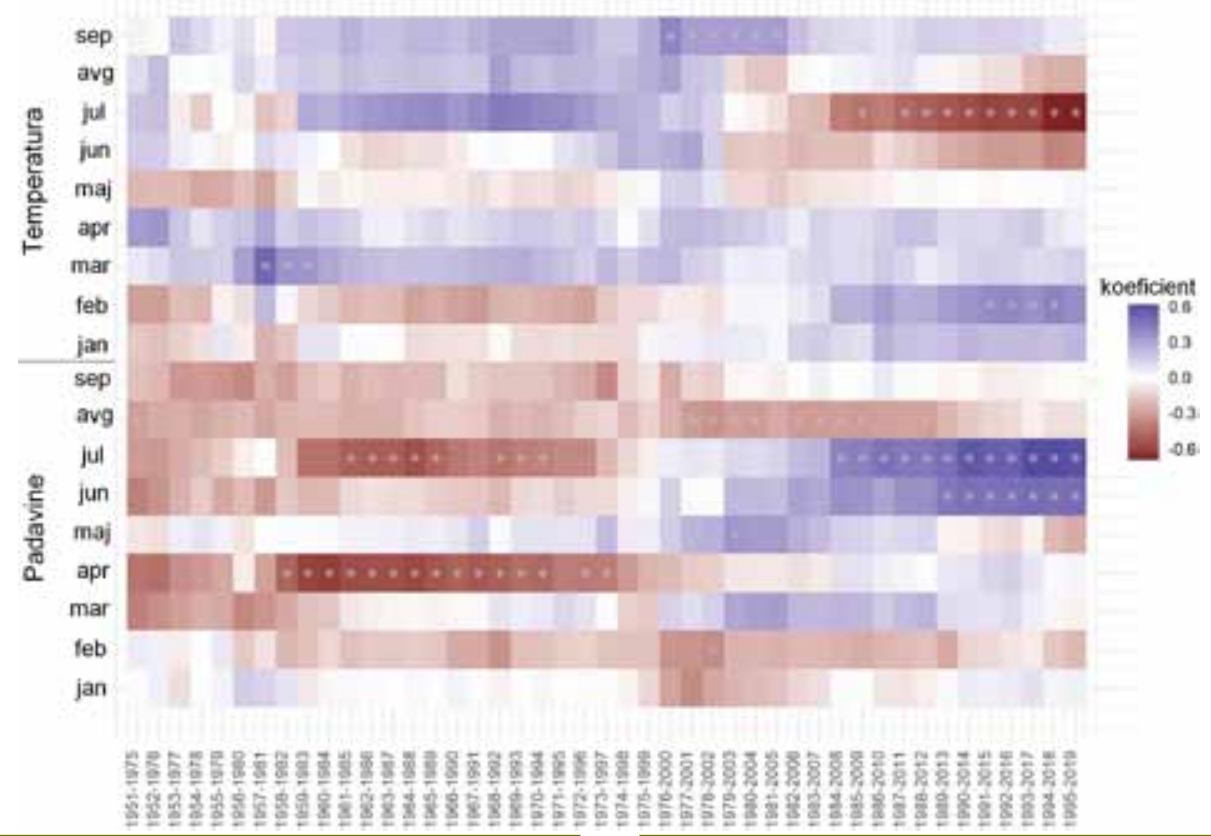

Slika 9: Odziv širine branike smreke na klimo po obdobjih na ploskvah pri Janšku. Vijolične barve ponazarjajo pozitivne odzive, rdeče barve pa negativne odzive.

\subsection{Analiza značilnih let}

3.5 Analysis of pointer years

$\mathrm{Z}$ analizo značilnih let smo preučevali vpliv klime na rast dreves vse od leta 1923 . V tem obdobju se značilna leta pojavijo šele po letu 1968. Opazimo lahko, da je bilo od leta 1968 do leta 201918 značilnih let. Z modro barvo so označena negativna značilna leta, pozitivna značilna leta pa z oranžno barvo.

Ocenjujemo, da sta bili leti 1994 in 1997 zelo ugodni za rast smreke in macesna, ker se je na vseh plo-
Fig. 9: Response of annual spruce ring width to the climate by periods on the plots near Janšek. Purples indicate positive responses and reds indicate negative responses.

skvah prirastek povečal. Nasprotno lahko ocenimo za leti 2002 in 2012, ki sta bili zelo neugodni za rast smreke in macesna. V letih 1986 in 2006 je bila klima zelo neugodna za rast smreke in zelo ugodna za rast macesna. Na podlagi doslej zbranih podatkov ne moremo sklepati o morebitnih vplivih klimatskih dejavnikov na ugodnejšo rast macesna $v$ značilnih letih. Podrobneje bi bilo treba raziskati dejavnike $\mathrm{v}$ neugodnih letih za rast smreke, čeprav je bila v letih 2006 in 2012 ocenjena suša nacionalnih razsežnosti (ARSO, 2017). 
Preglednica 6: Prikaz značilnih let na ploskvah Čofatije, Zdovca 11 in Janška. Značilna leta, ko je bil odziv dreves negativen, so označena z modro barvo, ko je bil odziv dreves pozitiven, pa z oranžno barvo. Izrazitost značilnega leta je označena z znaki + ali -. Neizrazita značilna leta so označena z znakom + (za pozitivna) in - (za negativna), izrazita značilna leta so označena z znakoma ++ ali - - in zelo izrazita z znaki +++ ali ---.
Table 6: Presentation of pointer years on the plots of Čofatija, Zdovc 11 and Janšek. Pointer years where the response of trees was negative are marked in blue, and where the response of trees was positive, they are marked in orange.

\begin{tabular}{|c|c|c|c|c|c|c|c|c|c|}
\hline \multirow{2}{*}{ Leto } & \multirow{2}{*}{ Čofatija } & \multicolumn{2}{|c|}{ Zdove } & \multirow{2}{*}{ Janšek } & \multirow{2}{*}{ Leto } & \multirow{2}{*}{ Čofatija } & \multicolumn{2}{|c|}{ Zdove } & \multirow{2}{*}{ Janšek } \\
\hline & & macesni & smreke & & & & macesni & smreke & \\
\hline 1968 & - & -- & - & & 1995 & -- & -- & --- & \\
\hline 1981 & & +++ & +++ & + & 1997 & ++ & +++ & +++ & ++ \\
\hline 1983 & + & & ++ & + & 2002 & --- & - & --- & - \\
\hline 1984 & --- & & -- & -- & 2003 & --- & - & & -- \\
\hline 1986 & -- & + & --- & -- & 2006 & --- & +++ & - & --- \\
\hline 1988 & - & --- & --- & & 2007 & + & + & & +++ \\
\hline 1989 & & + & +++ & + & 2012 & - & - & - & -- \\
\hline 1993 & --- & & --- & -- & 2013 & - & --- & & -- \\
\hline 1994 & ++ & + & ++ & + & 2018 & & - & --- & - \\
\hline
\end{tabular}

\section{RAZPRAVA}

\section{DISCUSSION}

Po 55 letih opazovanja sukcesijskega razvoja sestojev na nekdanjih novinah smo ocenili visoke sestojne gostote, primerljive s podobnimi raziskovanji v gozdnih rezervatih in gospodarskih gozdovih v Sloveniji. Kazalci sestojnih gostot SDI na ploskvah pri Čofatiji (SDI = 1286), Zdovcu (1215) in Janšku (1157) so primerljivi z vrednostmi, ki smo jih po objavljenih podatkih lahko izračunali za umetno osnovane smrekove sestoje na raziskovalnih ploskvah predalpskega jelovo-bukovega gozda Krašice pred prvim redčenjem (SDI med 1158 in 1289; Diaci, 1992) in v gozdnem rezervatu Poljšak, kjer je Firm (2006) na ploskvah macesna s smreko na nadmorski višini 1600 m ocenil vrednosti SDI = 1313. V subalpinskih smrekovjih, prepuščenih naravnemu razvoju, so bile vrednosti SDI ocenjene med 1200 in 1400 (Hladnik in Skvarča, 2009; Hladnik in Žižek Kulovec, 2014). Na Pahernikovi posesti je Murn (2017) v sestojih s prevladujočo smreko na primerljivi nadmorski višini kot v Koprivni ocenjeval sestojne gostote, iz katerih smo le na dveh ploskvah ocenili visoke vrednosti SDI med 1027 in 1046. Take vrednosti smo ocenili tudi po Halajevih tablicah donosov za gospodarske gozdove na Koprivni.

Smreka na nekdanjih novinah Koprivne z visokimi sestojnimi gostotami kaže podobno zmožnost vračanja in prevlade nad drugimi drevesnimi vrstami brez pomoči človeka in gozdnogojitvenih ukrepov, kot so njeno vračanje na območja nekdanjih novin ocenili na obširnih območjih južne Švedske (Lindbladh in sod., 2014).
Avtorji celo opozarjajo, da današnjega prevladovanja smreke ni mogoče pripisati le njenemu pospeševanju z intenzivnim gospodarjenjem po letu 1950. Tomson in sod. (2018) so v estonski gozdovih, v katerih so v preteklosti novinarili, ocenili ugodno obnovitev gozdov in tudi regeneracijo tal po novinarjenju.

Pri ocenjevanju sukcesijskega razvoja na Koprivni smo se oprli le na sestojne kazalce, pa tudi tukaj predolga obdobja med posameznimi meritvami niso dovoljevala podrobnejšega ocenjevanja priraščanja smreke. V deležu sestojne temeljnice je presegla polovico šele ob meritvah leta 1990, do leta 2017 pa je prevladala na skupinah ploskev pri Čofatiji z $82 \%$ deležem, pri Zdovcu z 91 \% in pri Janšku s 70 \% deležem v temeljnici (Golob in sod., 2019). Nedvoumnih ločnic za primerjavo in presojo o priraščanju smreke tudi ni mogoče postaviti zgolj na podlagi tablic donosov, kajti Pretzsch in sod. (2014) so pokazali na velike razlike v priraščanju sestojev, če primerjamo ocene pred letom 1960, do katerega so razvili večino tablic donosov, z obdobjem do leta 2000. Razmerje med povprečnim volumenskim prirastkom in povprečnim volumnom $\left(i_{v} / v\right)$ se je pri smreki iz nemških raziskovalnih ploskev povečalo za $25 \%$, pri bukvi pa celo za $57 \%$.

Primerjava s tablicami donosov in sestojnimi parametri v primerljivih gospodarskih gozdovih (Diaci, 1992; Kušar in sod., 2013) pokaže ob manjšem številu dreves večje srednjetemeljnične premere v gospodarskih gozdovih. Po redčenju v gospodarskih gozdovih se je del prirastka akumuliral na majhnem številu izbranih dreves. V sestojih na Koprivni, prepuščenih naravnemu razvoju, ob prevladovanju smreke poteka 
socialni sestop, ki ga najmočneje ponazarjajo deleži odmrlih dreves v spodnjem sloju, in značilne razlike v priraščanju dreves v zgornjem, srednjem in spodnjem sloju. V starejših sestojih je pričakovano tudi značilno zmanjšanje debelinskega prirastka dreves v zgornjem sloju, vendar bi bilo nezanesljivo sklepati o času morebitne kulminacije debelinskega prirastka zaradi predolgih opazovalnih obdobij 18 oziroma 27 let.

$\mathrm{Z}$ analizo vpliva klime na rast dreves pri Čofatiji nismo ocenili statistično značilnega vpliva klimatskih dejavnikov. Iz tega lahko sklepamo, da na prirastek bolj vplivajo rastišče in biotski dejavniki kot pa količina padavin in nihanje temperatur. Pri analizi vpliva klime na ploskvi Zdovc 11 smo ocenili, da na debelinsko priraščanje macesnov vpliva predvsem višina spomladanskih temperatur. Na rast smreke na ploskvi 11 pri Zdovcu vplivata predvsem višina minimalne temperature in višina povprečne temperature proti koncu zime. Vzrok za vpliv temperatur proti koncu zime lahko pripišemo dolžini zime, saj lahko daljša zima vpliva na manjši prirastek v tistem letu. Prav tako je lahko večji vpliv klime na rast dreves na tej ploskvi posledica slabših rastiščnih razmer, saj ploskev leži tik pod vrhom pobočja, na večji nadmorski višini in na območju z manjšo količino vode, saj v bližini ni vodotokov. Stopar (2018) je na primerljivih rastiščih prav tako ugotovil minimalne vplive temperatur in padavin na priraščanje smreke. Pri Janšku ima negativni vpliv na priraščanje količina padavin konec poletja. Do podobnih ugotovitev so prišli Levanič in sod. (2008), kajti v Sloveniji dendrokronološke analize smreke pogosto ne pokažejo povezav med klimo in prirastkom. V Sloveniji matična kamnina, relief in nadmorska višina pogosteje omejujejo rast smreke kot pa klimatski dejavniki (Levanič in sod., 2008). Z nadaljevanjem opazovanja rasti smreke na Koprivni bo mogoče sklepati o morebitnem vplivu klimatskih sprememb na njeno rast.

Na vseh skupinah ploskev je bilo ocenjeno, da se je spremenil odziv širine branik po obdobjih na povprečno temperaturo v mesecih junij, julij in avgust (Golob, 2020). V začetnih obdobjih je bil odziv v teh mesecih pozitiven, $\mathrm{v}$ zadnjih obdobjih pa je negativen. Makinen in sod. (2003) so ugotovili, da imajo na debelinski prirastek smreke v centralni in severni Evropi močan vpliv predvsem temperature $v$ juniju in juliju, kar potrjujejo naši izsledki o spremembah $\mathrm{v}$ odzivu širine branik po obdobjih. Ugotovili so tudi, da temperature $v$ različnih geografskih regijah različno vplivajo na debelinski prirastek (Makinen in sod., 2003).

Z dendrokronološko analizo smo po letu 1968 ocenili 11 negativnih značilnih let $(1984,1986,1988$, 1993, 1995, 2002, 2003, 2006, 2012, 2013, 2018). Pri primerjavi negativnih značilnih let s podatki agencije ARSO o sušah v Sloveniji (ARSO, 2017; ARSO, 2020) smo ugotovili, da so bile v letih 1984, 1988, 1993, 2003, 2006, 2012, 2013 in 2018 v Sloveniji suše nacionalne razsežnosti. Na podlagi podatkov najbližje klimatološke postaje Ravne na Koroškem je mogoče za leto 1986 sklepati o sušnih razmerah v vegetacijski dobi. Po letu 1990 pa na klimatološki postaji Ravne na Koroškem ni več na voljo podatkov (ARSO, 2020). Podobno velja tudi za postajo na Uršlji gori (1699 m nadmorske višine), saj so bili na voljo le podatki do leta 1993. Zanimiva je primerjava z izsledki o značilnih letih za smreko, ki jih je na sedmih lokacijah v Sloveniji ocenjeval Stopar (2018). Enako, kot smo ocenili na območju Koprivne, je za leto 1995 ocenil negativne odzive na klimatske razmere na Pohorju, Pokljuki in Mašunu. V letu 2002 pa le na Pohorju in na Pokljuki, čeprav v teh dveh letih niso poročali o suši nacionalnih razsežnosti (ARSO, 2017). O razlogih za podobne negativne odzive dreves na območjih Karavank, Pohorja in Julijskih Alp bo mogoče sklepati z nadaljevanjem raziskovanja.

\section{POVZETEK}

\section{SUMMARY}

The paper assesses spruce and larch growth on forest research plots located in former slash-and-burn areas in Koprivna, an Alpine valley in northern Slovenia. Koprivna is geologically and geographically a part of the Karavanke range with a characteristically diverse geological structure (Fig. 1 and 2). The climate in Koprivna is Alpine. Winters are long and cold, and snow persists until late spring. Summers are short and warm, and the growing season lasts from May to September (Golob, 2018).

On research plots in former slash-and-burn areas, forest successional development has been monitored since 1962. Measurements were subsequently conducted in 1965, 1968, 1972, 1990 and 2017. Based on past measurements (Golob, 1992; Golob, 2018) on the permanent research plots, changes in quadratic mean diameter, dominant diameter, dominant height, the number of trees per hectare, stand density index, basal area and growing stock were determined. The impact of climate as one of the potential factors affecting growth and development of trees in Koprivna area was examined. Cores for dendrochronological analysis were sampled on the research plots in September 2019 (Table 1). The cores of 20 spruces were sampled on plots on the Janšek and Čofatija farmsteads, and the cores of 10 spruces and 10 larches were sampled on the Zdovc 11 plot. Two cores were sampled on each tree to align the chronologies. 
Three graphical methods were used to present the results on the impact of climate on diameter increment. The first shows a standard chronology (Fig. 4). The second shows a simple Pearson correlation, which illustrates which parameter in a certain month best explains variations in ring width (Fig. 8). The third shows the response of ring width to climate by periods (Fig. 9). A separate analysis was made of pointer years - years in which most trees have the same response relative to the prior year (Table 6).

The number of trees decreased substantially with successional development of forest stands on the research plots. From the first to the last measurement, the number of trees decreased by $78.3 \%$ on the Čofatija plots and $95.9 \%$ on the Zdovc plots (Table 2). Growing stock was calculated according to tariffs and two-entry volume tables. The volume of dead trees between periods was also calculated to produce the growing stock with included mortality. Volume increments during the measurement in periods were calculate based on growing stock. Stand parameters on the plots were compared with Halaj and Swiss yield tables, and site productivity was determined (Table 2). The ratio between average volume increment and tree volume $\left(i_{v} / v\right)$ was used for comparison with the data in Halaj yield tables. Because measurement periods were 18 and 27 years in Koprivna, estimates from comparable research plots with shorter measurement periods were added for comparison (Fig. 5). For trees on the Čofatija plots, significantly higher $i_{v} / v$ values than values in the yield tables were confirmed for all periods; for the last period until 2017 the same applied to the trees on the Janšek plot $(p<0.01)$ and Zdovc plot $(p<0.05)$.

Data from past measurements on 13 research plots was used to calculate diameter increments of spruce and larch, which were then compared with the dendrochronological data analysis, for which trees in the upper layer were selected (Fig. 6 and 7). In the analysis of diameter increments by layer, significant differences $(p<0.01)$ in increment were determined between trees in the upper layer and trees in the middle and bottom layer (Fig. 6 and 7). In the last period a significantly lower $(p<0.01)$ spruce increment was determined in the upper layer on the Čofatija plots; on the Zdovc plot larch increment was significantly lower as well $(p<0.01)$. The diameter increment of spruce in the upper layer on the Janšek plot increased from the initial period, but in the last two periods no significant differences were determined.

The influence of temperature and precipitation on the growth of spruce and larch was investigated by dendrochronological analysis. The analysis of radial increment showed that the response of tree-ring width changed in the last period. There were more negative responses of tree-ring width to above average and below average precipitation in recent periods. This was confirmed by pointer year analysis as there were more negative pointer years in the last period (Table 6); there were 11 negative pointer years from 1968 to 2019. The years 1994 and 1997 were very favourable for the growth of spruce and larch, with increment increases on all plots. On the other hand, 2002 and 2012 were very unfavourable for spruce and larch growth. The comparison of site conditions on the experimental plots shows that site characteristics and biotic factors have a greater influence on diameter growth than precipitation or temperature fluctuations. In Slovenia, bedrock, relief and altitude are more often limiting factors for spruce growth than climatic factors (Levanič et al., 2008). Due to the favourable locations on the Koprivna research plots, the influence of climate on diameter increment is low - climate is not a decisive limiting factor.

\section{ZAHVALA}

\section{ACKNOWLEDGEMENTS}

Raziskava je bila opravljena v okviru priprave magistrskega dela Janez Goloba, ki je v času študija na magistrskem študijskem programu druge stopnje Gozdarstvo in upravljanje gozdnih ekosistemov prejemal štipendijo Pahernikove ustanove.

\section{VIRI}

\section{REFERENCES}

ARSO. 2017. Ocena tveganja za sušo, Slovenija. Agencija RS za okolje https://meteo.arso.gov.si/uploads/probase/www/agromet/OT/ Ocena_tveganja_Susa_DOPOLNJENA_PS.pdf (15. 5. 2020).

ARSO. 2020. Ocena tveganja za sušo, Slovenija. Agencija RS za okolje https://meteo.arso.gov.si/met/sl/archive/ (20.5. 2020).

Cybis Elektronik \& Data AB. 2019.CooRecorder in CDendro www. cybis.se (5. 5. 2020).

Cividini R., Wraber M. 1950. Gozdarski inštitut Slovenije v letih 1947-1949. Izvestja, 1: 1-22.

Čokl M. 1961. Raziskovalne ploskve v prebiralnih gozdovih na Snežniku v razdobju 1949-1960. Ljubljana, IGLG: 92 str.

Čokl M. 1971. Raziskovalne ploskve v Blejskem gozdnogospodarskem območju. Ljubljana, IGLG: 49 str.

Diaci J. 1992. Učinek izbiralnih redčenj na različne sestojne parametre umetno osnovanega smrekovega gozda na rastišču predalpskega jelovo-bukovega gozda. Gozdarski vestnik, 50, 2: 66-82.

Diaci J. 2006. Gojenje gozdov: pragozdovi, sestoji, zvrsti, načrtovanje, izbrana poglavja. Ljubljana, UL, Biotehniška fakulteta, Oddelek za gozdarstvo in obnovljive gozdne vire, 348 str.

Firm D. 2006. Razvoj visokogorskih gozdov v rezervatu Polšak: diplomsko delo. (Univerza v Ljubljani, Biotehniška fakulteta, Oddelek za Gozdarstvo in obnovljive gozdne vire). Ljubljana, samozaložba: 78 str. 
Golob M. 1992. Naravni razvoj pionirskega gozda na novinah v Koprivni: diplomsko delo. (Univerza v Ljubljani, Biotehniška fakulteta, Oddelek za gozdarstvo). Ljubljana, samozaložba: 159 str.

Golob J. 2018. Razvoj gozdnih sestojev na nekdanjih novinah v Koprivni: diplomsko delo. (Univerza v Ljubljani, Biotehniška fakulteta, Oddelek za gozdarstvo in obnovljive gozdne vire). Ljubljana, samozaložba: 73 str.

Golob J., Golob M., Hladnik D. 2019. Razvoj gozdnih sestojev na nekdanjih novinah v Koprivni. Acta Silvae et Ligni, 120: 29-44.

Golob J. 2020. Priraščanje navadne smreke (Picea abies (L.) Karst.) in evropskega macesna (Larix decidua Mill.) na nekdanjih novinah v Koprivni: mag. delo. (Univerza v Ljubljani., Biotehniška fakulteta., Oddelek za gozdarstvo in obnovljive gozdne vire). Ljubljana, samozaložba: 83 str.

GURS. 2016. Ciklično aerosnemanje Slovenije (ortofoto posnetki). Ljubljana, Geodetska uprava RS http://www.e-prostor.gov.si/ zbirke-prostorskih-podatkov/topografski-in-kartografski-podatki/ortofoto/ (12. 6. 2018).

Hladnik D., Skvarča A. 2009. Gozdarske raziskovalne ploskve in stalne vzorčne ploskve na območjih Natura 2000 na Slovenskem. Gozdarski vestnik, 67, 1: 3-16, 49-52.

Hladnik D., Žižek Kulovec L. 2014. Consistency of stand density estimates and their variability in forest inventories in Slovenia. Acta Silvae et Ligni, 104: 1-14.

Hladnik D., Levanič T. 2021. Primerjava dendrokronoloških raziskovanj z ocenjevanjem prirastka na gozdarskih raziskovalnih ploskvah. Gozdarski vestnik, 79, 3: 115-131.

Knibbe B. 2018. SCIEM - Scientific Engineering \& Manufacturing. PAST - Personal AnalysisSystemforTreeringresearch. http:// www.sciem.com/products/past/ (5. 5. 2020).

Koehl M., Scott C.T., Zingg A. 1995. Evaluation of permanent sample surveys for growth and yield studies: a Swiss example. Forest Ecology and Management, 71, 187-194.

Kotar M. 1998. Proizvodnja sposobnost visokogorskih in subalpinskih gozdnih rastišč ter zgradba njihovih gozdov. Gorski gozd, zbornik referatov XIX. Gozdarski študijski dnevi, Ljubljana, Biotehniška fakulteta, Oddelek za gozdarstvo in obnovljive gozdne vire: $109-124$

Kotar M. 1980. Gozdarski priročnik: tablice. 5. izd. Ljubljana, Biotehniška fakulteta, VTOZD za gozdarstvo: $374 \mathrm{str}$

Kotar M. 2007. Gozdarski priročnik: tablice. 7. izd. Ljubljana, Biotehniška fakulteta,Oddelek za gozdarstvo in obnovljive gozdne vire: 414 str.

Kotar M. 2011. Zgradba, rast in donos gozda na ekoloških in fizioloških osnovah. Ljubljana, Zveza gozdarskih društev, Zavod za gozdove Slovenije: $500 \mathrm{str}$.

Kušar G., Hladnik D., Hočevar M. 2013. Zanesljivost volumenskih funkcij na primeru drevesne vrste smreke v Sloveniji. Acta Silvae et Ligni, 102: 43-54.

Levanič T., Gričar J., Gagen M., Jalkanen R., Loader N.J., McCarroll D., Oven P., Robertson I. 2008. The climate sensitivity of Norway spruce (Picea abies (L.) Karst.) in the southeastern European Alps. Trees, 23: 169-180.

Levanič 2007. ATRICS - A new system for image acquisition in dendrochronology. Tree Ring Research, 63, 2: 117-122.
LIDAR. 2015. Ljubljana, Agencija RS za okolje. http://gis.arso.gov.si/ evode/profile.aspx?id=atlas_voda_Lidar@Arso (9.9. 2017).

Lindbladh M., Axelsson A.L., Hultberg T., Brunet J., Felton A. 2014. From broadleaves to spruce - borealization of southern Sweden. Scandinavian Journal of Forest Research, 29, 1: 686-696.

Marell A., Leitgeb E. 2005. Field research and monitoring of Europe's forests: a historical perspective. V: European long-term research for sustainable forestry: experimental and monitoring assets at the ecosystem and landscape level: technical Report 3, COST Action E25. Paris Cedex, Groupement d'Intérêt Public Ecosystème Forestiers: 1-35.

Makinen H., Nojd P., Kahle H.P., Neumann U., Tveite B., Mielikainen K., RohleHeitz., Spiecker H. 2003. Large-scale climatic variability and radial increment variation of Picea abies (L.) Karst. in central and northern Europe. Trees, 17: 173-184.

Mlinšek D. 1968. Sproščena tehnika gojenja gozdov na osnovi nege. Ljubljana, Poslovno združenje gozdnogospodarskih organizacij v Ljubljani: 117 str.

Murn T. 2017. Rastne značilnosti smreke na bukovih rastiščih z belkasto bekico v Pahernikovih gozdovih: diplomsko delo. (Univerza v Ljubljani, Biotehniška fakulteta, Oddelek za Gozdarstvo in obnovljive gozdne vire). Ljubljana, samozaložba: 21 str.

Pretzsch H., Biber P. 2005. A Re-Evaluation of Reinke's Rule and Stand Density Index. Forest Science, 51, 4: 304-320.

Pretzsch H., Biber P., Schütze G., Uhl E., Rötzer T. 2014. Forest stand growth dynamics in Central Europe have accelerated since 1870. Nature Communications, 5: 4967.

Pretzsch H., Schütze G., Biber P., 2018. Drought can favour the growth of small in relation to tall trees in mature stands of Norway spruce and European beech. Forest Ecosystems, 5: 20.

Pretzsch H., del Rio M., Biber P., Arcangeli C., Bielak K., Brang P., Dudzinska M., Forrester D.I., Klaedtke J., Kohnle U., Ledermann T., Matthews R., Nagel J., Nilsson U., Ningre F., Nord-Larsen T., Wernsdoerfer H., Sycheva E. 2019. Maintenance of long-term experiments for unique insights into forest growth dynamics and trends: review and perspectives. European Journal of Forest Research, 138: 165-185.

R Core Team. 2020. R: A language and environment for statistical computing. Vienna, R Foundation for Statistical Computing http://www.R-project.org/ (9. 9. 2021).

Stopar S. 2018. Dendrokronološka analiza debelinskega priraščanja smreke (Picea abies (L.) Karst.) na območju njene naravne in umetne razširjenosti v Sloveniji: diplomsko delo. (Univerza v Ljubljani, Biotehniška fakulteta, Oddelek za Gozdarstvo in obnovljive gozdne vire). Ljubljana, samozaložba: 64 str.

The Copernicus Climate Change Service. 2020. E-OBS data accesshttps://surfobs.climate.copernicus.eu/dataaccess/access eobs.php (21. 2. 2020)

Tomson P., Kaart T., Sepp K. 2018. Role of 19th-century rotational slash-and-burn cultivation in the development of boreal forests in southern Estonia and implications for forest management. Forest Ecology and Management, 409: 845-862.

ZGS. 2020. Prostorski podatki o gozdnih združbah. Zavod za gozdove Slovenije, Območna enota Slovenj Gradec. (neobjavljano) 